\title{
How Antibodies Recognize Pathogenic Viruses: Structural Correlates of Antibody Neutralization of HIV-1, SARS-CoV-2, and Zika
}

\author{
Morgan E. Abernathy ${ }^{1,+}+^{\mathbb{D}}$, Kim-Marie A. Dam ${ }^{1,+}+\mathbb{D}$, Shannon R. Esswein ${ }^{2,+} \mathbb{D}$, Claudia A. Jette ${ }^{1,+}$ \\ and Pamela J. Bjorkman ${ }^{1, *(D)}$ \\ 1 Division of Biology and Biological Engineering, California Institute of Technology, Pasadena, CA 91125, USA; \\ mabernat@caltech.edu (M.E.A.); kdam@caltech.edu (K.-M.A.D.); cajette@caltech.edu (C.A.J.) \\ 2 David Geffen School of Medicine at University of California, Los Angeles, CA 90095, USA; \\ sesswein@caltech.edu \\ * Correspondence: bjorkman@caltech.edu; Tel.: +1-(626)-395-8350 \\ + These authors contributed equally.
}

Citation: Abernathy, M.E.; Dam, K.A.; Esswein, S.R.; Jette, C.A.; Bjorkman, P.J. How Antibodies Recognize Pathogenic Viruses: Structural Correlates of Antibody Neutralization of HIV-1, SARS-CoV-2, and Zika. Viruses 2021, 13, 2106. https://doi.org/10.3390/v13102106

Academic Editor: David Stuart

Received: 16 September 2021

Accepted: 12 October 2021

Published: 19 October 2021

Publisher's Note: MDPI stays neutral with regard to jurisdictional claims in published maps and institutional affiliations.

Copyright: (c) 2021 by the authors. Licensee MDPI, Basel, Switzerland. This article is an open access article distributed under the terms and conditions of the Creative Commons Attribution (CC BY) license (https:// creativecommons.org/licenses/by/ $4.0 /)$.

\begin{abstract}
The H1N1 pandemic of 2009-2010, MERS epidemic of 2012, Ebola epidemics of 20132016 and 2018-2020, Zika epidemic of 2015-2016, and COVID-19 pandemic of 2019-2021, are recent examples in the long history of epidemics that demonstrate the enormous global impact of viral infection. The rapid development of safe and effective vaccines and therapeutics has proven vital to reducing morbidity and mortality from newly emerging viruses. Structural biology methods can be used to determine how antibodies elicited during infection or vaccination target viral proteins and identify viral epitopes that correlate with potent neutralization. Here we review how structural and molecular biology approaches have contributed to our understanding of antibody recognition of pathogenic viruses, specifically HIV-1, SARS-CoV-2, and Zika. Determining structural correlates of neutralization of viruses has guided the design of vaccines, monoclonal antibodies, and small molecule inhibitors in response to the global threat of viral epidemics.
\end{abstract}

Keywords: antibody; cryo-electron microscopy; HIV-1; SARS-CoV-2; structural biology; virus; X-ray crystallography; Zika

\section{Introduction}

Advances in structural biology in recent decades have played a key role in the determination of disease-relevant protein complexes and guided the design of new therapeutics and vaccines. An early pioneer in structural biology was the X-ray crystallographer Rosalind Franklin. While she is best known for her role in collecting the X-ray fiber diffraction patterns that revealed the 3D structure of DNA, her contributions in biologically-related fields also included insights into the structures of protein encapsulated viruses such as tobacco mosaic virus (TMV), poliovirus, and turnip yellow mosaic virus. During Franklin's studies of viruses in the 1950s, a central question was how viruses managed to build a protein shell to shield their genetic material given that only a limited number of viral capsid proteins could be encoded within a viral genome based on capsid size constraints. Franklin's X-ray analysis revealed the arrangement of the protein subunits in TMV, allowing her to create the first three-dimensional model of a virus [1-4]. Following this work, she used X-ray data to determine the position and orientation of RNA packaged inside of the rod-shaped TMV [5]. Unlike prior speculation that placed the RNA at the center of the rod, her work revealed the virus was hollow, which led to the discovery that the RNA spiraled with the helical protein capsid. This work was fundamental in understanding principles of virus structure. Franklin's contributions to the field of virology are summarized on her tombstone, which reads, "Her research and discoveries on viruses remain of lasting benefit to mankind." Together, her remarkable contributions to structural studies in three separate 
areas, DNA, coal, and viruses, before her death at the age of 37 make her an inspiration to future generations of structural biologists, particularly women. We are proud to follow in her footsteps to use structural biology to gain insight into viruses with the goal of providing benefits to human health.

The severe acute respiratory syndrome coronavirus (SARS-CoV) epidemic of 2002, Middle East Respiratory Syndrome (MERS) epidemic of 2012, acquired immune deficiency syndrome (AIDS) pandemic starting in 1981, the Zika virus (ZIKV) epidemic of 2015-2016, and the ongoing SARS-CoV-2/COVID-19 pandemic are examples of the enormous global burden of viruses and the urgent need for vaccine and therapeutic development. Building on the prior contributions of early pioneers such as Rosalind Franklin, structural biologists continue to advance techniques in X-ray crystallography and cryo-electron microscopy (cryo-EM) to investigate viruses and viral proteins. We are interested in investigating antibody $(\mathrm{Ab})$ recognition of viruses, which we do by solving 3D structures of viral proteins bound to Abs elicited by infection or vaccination. Understanding the structural correlates of $\mathrm{Ab}$ recognition of viruses is key for the development of effective monoclonal $\mathrm{Ab}$ therapies and vaccines (Figure 1).

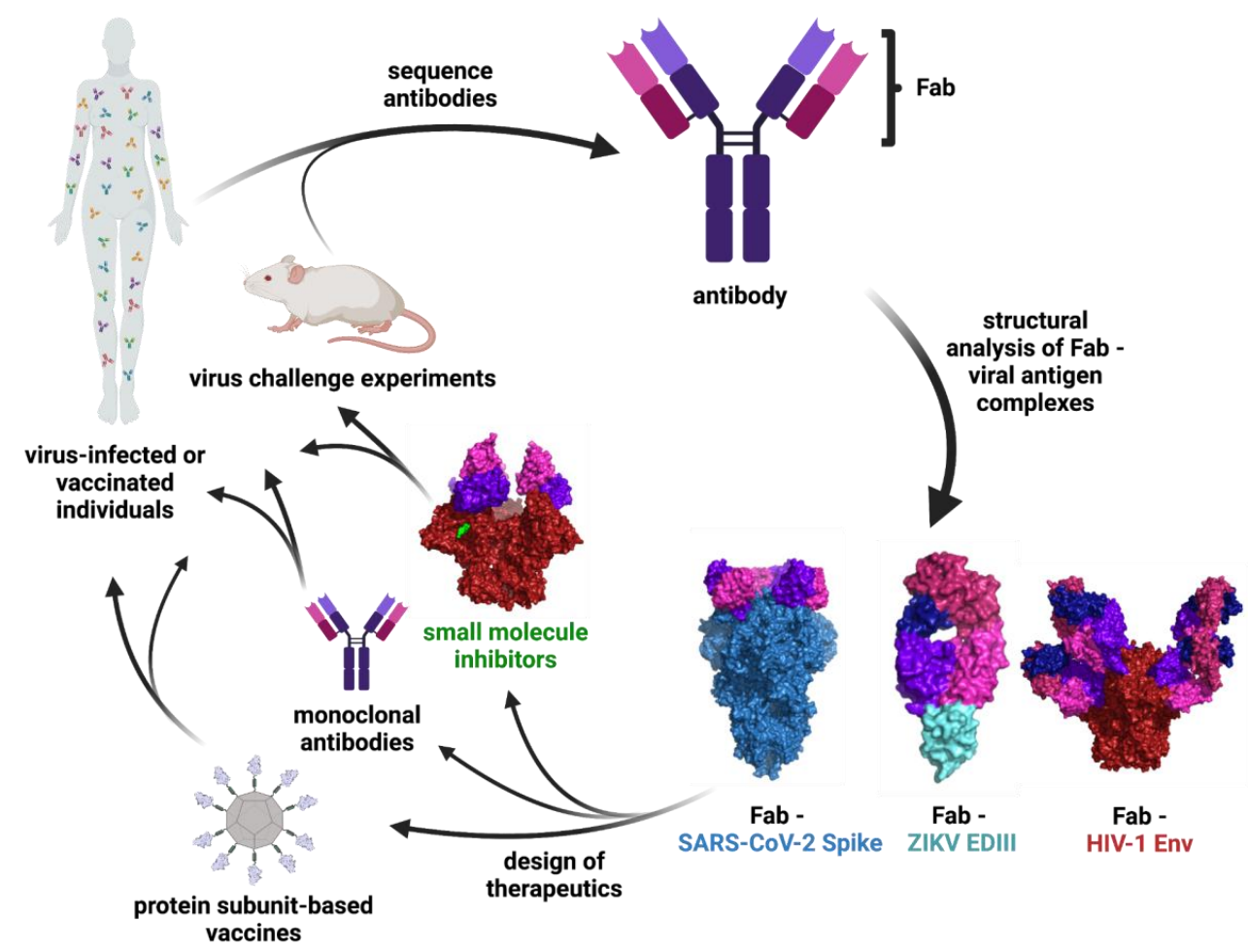

Figure 1. Schematic of $\mathrm{Ab}$ characterization and therapeutic development. The binding epitopes of Abs isolated from infected or vaccinated individuals or animal studies are determined through structural analysis of Fab-viral antigen complexes. These structures inform the design of vaccines, monoclonal Abs, and small molecule therapeutics that can be tested in clinical trials and animal models. Surface representations are shown for the following structures: Fab-SARS-CoV-2 S (PDB 7K90), Fab-ZIKV EDIII (PDB 5VIG), Fab-HIV-1 Env (PDB 5T3Z), and small molecule inhibitorHIV-1 Env (PDB 7LO6).

Human immunodeficiency virus 1 (HIV-1) is responsible for the AIDS pandemic and 36 million deaths to date [6] and has long posed a challenge for vaccine development due its remarkable ability to evade the host immune response and establish latent reservoirs. HIV-1 contains a single viral protein on its surface that facilitates infection of immune cells. This protein, named Envelope or Env, is a trimer of gp120/gp41 heterodimers (Figure 2A). The gp120 portion of Env interacts with host CD4 receptors, which stimulates conformational changes that allow binding to the co-receptor, usually a host chemokine 
receptor called CCR5 [7]. These events trigger rearrangements in gp41 that allow fusion of the viral and host cell membranes, which is required for entry of the HIV-1 genome into the host cell [7]. In addition to small molecule anti-retroviral drug treatments to treat infected individuals, current strategies to prevent HIV-1 infection include vaccine design. Vaccine efforts seek to stimulate the evolution of broadly neutralizing Abs (bNAbs) that have been isolated in rare cases of human HIV-1 infection and are capable of broad and potent protection [8-10]. Advances in X-ray crystallography and cryo-EM have given us the invaluable opportunity to structurally characterize bNAb interactions with Env and Env conformational changes which have informed vaccine design efforts.

A

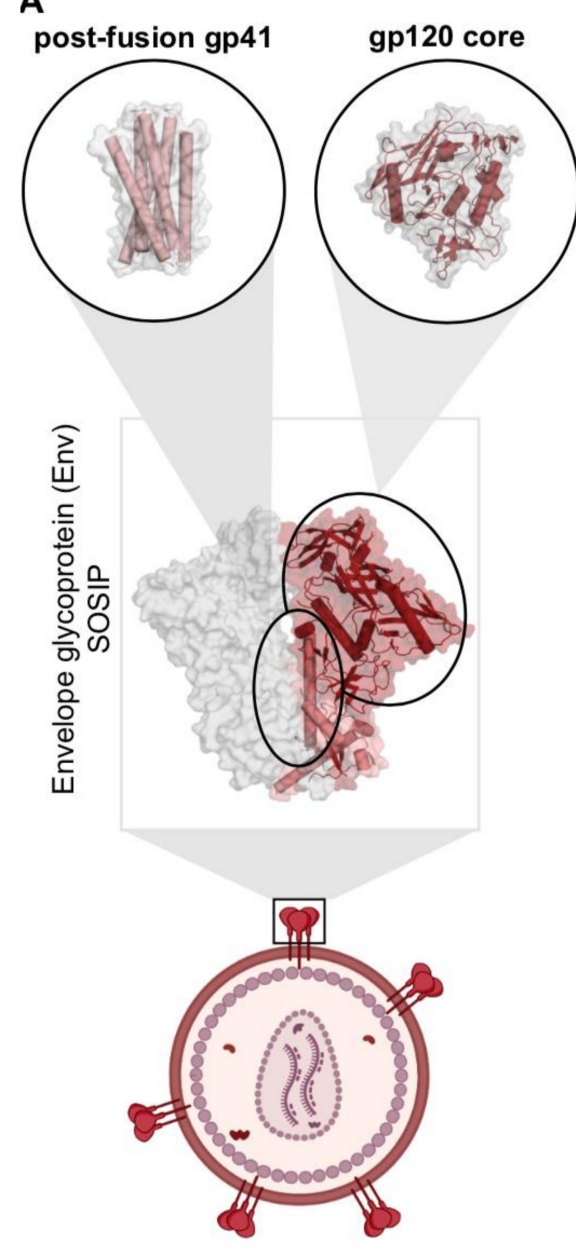

HIV-1
B
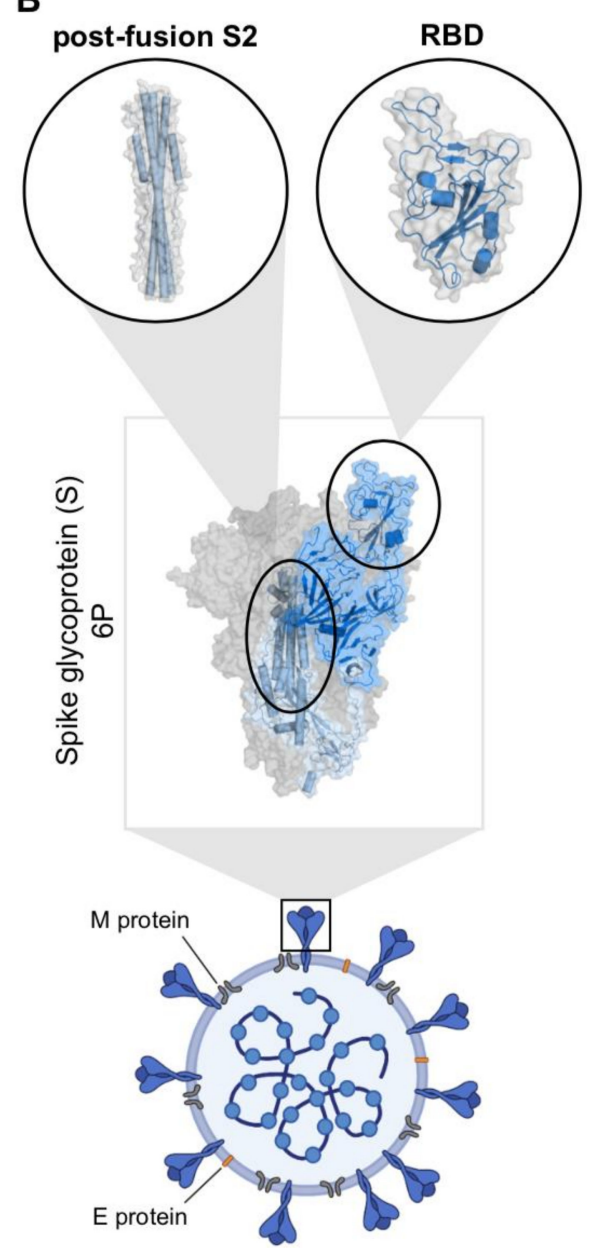

SARS-CoV-2
C

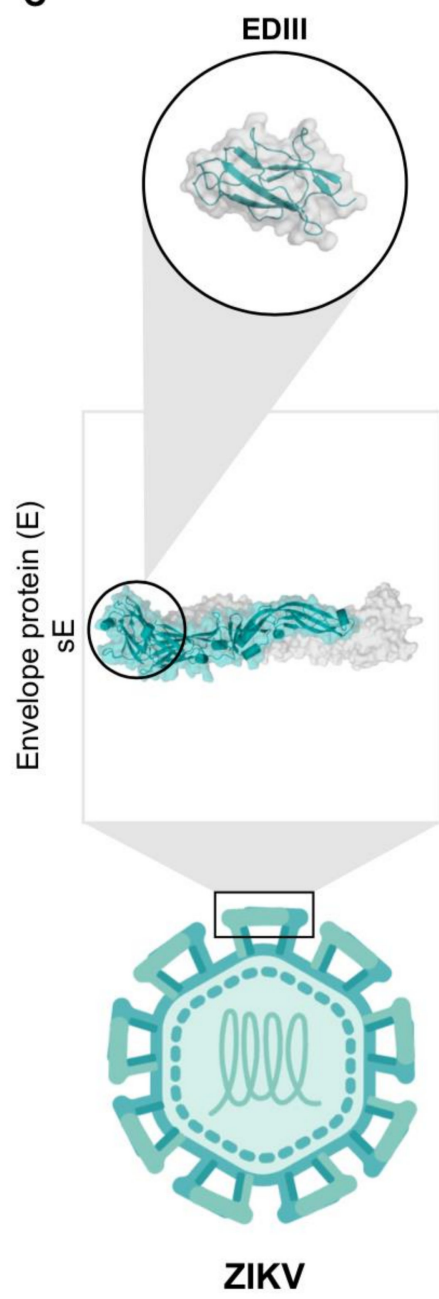

Figure 2. Structural targets of HIV-1, SARS-CoV-2, and ZIKV. (A) Cartoon HIV-1 virion with a closed, pre-fusion Env protein structure highlighted (PDB: 6UDJ). Circles show crystal structures of the postfusion gp41 bundle (left, PDB: 1AIK) and gp120 core (right, PDB: 5F4P). (B) Cartoon SARS-CoV-2 virion with S protein (blue), M protein (grey), and E protein (orange). The closed, pre-fusion S protein structure with one 'up' RBD (blue subunit) and two 'down' RBDs (grey subunits) is shown in the box (PDB: 7K8V). Circles show postfusion S2 helices (left, PDB: 6LXT) and RBD (right, PDB: 7K8M) structures. (C) Cartoon ZIKV virion with E protein (teal). The soluble E (sE) protein dimer structure is shown in the box with one $\mathrm{E}$ protein highlighted (PDB: 5JHM). The EDIII structure is shown in the circle (PDB: 6UTA).

SARS-CoV-2, the virus responsible for the COVID-19 pandemic, has caused 4.5 million deaths and an estimated 225 million infections as of September 2021 [11]. The spike (S) proteins on the surface of SARS-CoV-2 allow it to infect host cells by binding the host cellular angiotensin-converting enzyme 2 (ACE2) receptor [12,13]. Each of the three protomers on an S protein includes two subunits, S1 and S2. The receptor binding domain (RBD) on 
$\mathrm{S} 1$ is the component that recognizes ACE2 during cell entry (Figure 2B) [13-16]. While the RBD can adopt both 'up' and 'down' conformations, it can only bind ACE2 when it is an 'up' conformation [14-20]. Due to the critical role of the RBD in facilitating infection, neutralizing Abs that target the RBD are an important component of the immune response against SARS-CoV-2 [21-31]. Structural biology has been instrumental in the rapid characterization and evaluation of the $S$ protein and Abs produced in natural infection $[15,21-33]$. This work has contributed to the development of COVID-19 vaccines and monoclonal $\mathrm{Ab}$ $(\mathrm{mAb})$ therapeutics, which have saved countless lives.

ZIKV is a mosquito-borne virus that can cause microcephaly and neurodevelopmental abnormalities in the newborns of infected mothers [34-37]. As part of the flavivirus genus, ZIKV shares similar features as other widespread flaviviruses such as dengue (DENV), West Nile virus (WNV), and yellow fever virus (YFV) [38-41]. Mature ZIKV has seven non-structural proteins (NS1, NS2A, NS2B, NS3, NS4A, NS4B and NS5) and three structural proteins: envelope (E), membrane (M), and capsid (C) [42-44]. The surface of ZIKV is coated by 180 copies of the $E$ protein arranged as 90 dimers, and each $E$ protein includes three ectodomains, EDI, EDII, and EDIII (Figure 2C) [38,42,43]. The flexible regions between the domains allows dynamic conformational changes to occur during viral entry and fusion [38,45-48]. EDII contains a conserved fusion loop (FL) peptide that becomes exposed after viral entry into cells and initiates endosomal fusion [42,43,49,50]. EDIII is thought to be important for receptor binding during infection, and consequently, is an important target for neutralizing Abs [51-56]. There is not yet a safe and effective vaccine against ZIKV that is universally available.

Here we review how approaches in structural and molecular biology have increased our understanding of Ab recognition of HIV-1, SARS-CoV-2, and ZIKV. We discuss how the design of stable and soluble viral antigens amenable for structural approaches has enabled our ability to analyze complexes of viral antigens bound by the antigen binding fragment (Fab) of Abs. Use of both cryo-EM and X-ray crystallography has increased our understanding of key viral epitopes targeted by Abs and conformational changes of viral proteins necessary for infection. These structural insights, combined with analyses of the levels of somatic hypermutation found in potently neutralizing Abs, provide valuable information for the development of effective vaccines and monoclonal $\mathrm{Ab}$ therapies to reduce global morbidity and mortality from epidemic/pandemic-causing viruses.

\section{Main Body}

\subsection{Engineering Viral Surface Proteins for Structural Studies}

Structural biology techniques such as X-ray crystallography and single particle cryoEM require samples that are stable enough to be isolated and manipulated in the laboratory. For some viruses, especially those that are symmetric, it is feasible to structurally characterize intact viruses using cryo-EM. For example, cryo-EM structures of intact, whole ZIKV have been solved with and without Fabs of Abs bound [42,43,57-62]. Viruses with pleomorphic structures (e.g., most enveloped viruses) can also be investigated structurally using cryo-electron tomography [63-65]. In order to prepare surface viral proteins of enveloped viruses for structural studies and therapeutic development, it has been necessary to produce soluble, native-like versions that are stabilized in a pre-fusion conformation that is targeted by neutralizing Abs.

Classically, the simplest way to solubilize a surface viral protein is to remove the transmembrane and cytoplasmic domains by truncation [66,67]. Truncation has also been used to produce smaller components such as single domains. Examples of truncated domains include gp120 cores of HIV-1 Env, which have the $\beta 4$ and $\beta 26$ strands and all flexible loops removed $[68,69]$, coronavirus RBDs truncated at the base where the flexible hinge connects them to the rest of the S1 subunit [70,71], and the individual EDIII truncated from the rest of the ZIKV E protein [52-54,72,73]. Truncation of individual domains has been especially powerful for X-ray crystallography as crystallization is hindered by flexible regions such as loops or inter-domain linkers and hinges. Single domains are useful for 
solving high resolution structures of Fab-domain complexes that provide detail about the $\mathrm{Ab}$ interactions that may not be possible using single particle cryo-EM due to flexibility or heterogeneity of larger protein complex structures [32,52-54,72-74].

While truncated proteins have been useful in the field of structural biology, they do not necessarily reflect all aspects of the whole antigen and cannot always recapitulate the properties of a native viral protein. An extra layer of complexity exists since many viral proteins adopt distinct conformations depending on the step in the viral life cycle, requiring engineering and stabilization of the desired conformation for larger, multi-subunit complexes [43,46,47,57]. Fusion proteins such as Env and S include folded helical bundles that must extend for fusion of the viral and host cell membrane bilayers. These proteins are metastable in their pre-fusion conformation, which is usually the target of neutralizing Abs [75]. The introduction of stabilizing mutations can be helpful for preparing soluble constructs of larger, multi-subunit complexes. For example, helix-breaking proline mutations have been introduced into the central helices of fusion proteins, preventing the extension of helices required for membrane fusion [76]. In combination with an intersubunit disulfide bond and truncation after residue 664, these mutations were introduced into HIV-1 Env to produce the pre-fusion stabilized SOSIP.664 trimers [77]. The proline helix-breaking stabilizing mutations have been successfully adapted to other viral fusion proteins including those on coronaviruses, RSV, Ebola virus, human metapneumovirus, and Lassa virus [75]. For SARS-CoV-2 S, additional prolines were introduced that further stabilize the trimer in the 6P, or 'HexaPro' version [67]. For studies of the ZIKV E protein soluble constructs of both monomeric E protein [56,78-80] and engineered disulfide-linked E protein dimers $[55,81]$ have been designed.

Most regions of proteins have a purpose that is important to their function, particularly transmembrane regions and cytoplasmic tails [82]. Consequently, truncated and stabilized proteins used as substitutes for full-length equivalents are only useful to the extent that they are able to approximate the native state of the protein. It is essential for the engineered forms used for structural studies to be characterized with non-structural methods to confirm that they behave in a similar fashion to the native form in the context they are being studied.

\subsection{Dominant Ab Epitopes on Viral Fusion Proteins}

Structural analysis has facilitated identification of neutralizing epitopes on HIV-1, SARS-CoV-2 and ZIKV. Both X-ray crystallography and cryo-EM analyses of viral antigens in complex with neutralizing Ab Fabs have provided insights into mechanisms of neutralization by Abs and identified new therapeutic targets [7,32]. Neutralizing epitopes tend to be in structurally functional regions, and in many cases facilitate or hinder a structural change. In addition to neutralizing Abs, an immune response to a pathogen or vaccine can produce weakly neutralizing or non-neutralizing antibodies. which can be protective through various mechanisms such as antibody dependent cell cytotoxicity (ADCC) [83-86]. For viral fusion, there is typically a dramatic conformational change that occurs in the fusion protein to expose receptor binding sites for attachment and to insert the fusion machinery into the target membrane to undergo fusion [87]. Requiring a large conformational change is a strategy that allows viruses to hide vulnerable regions that are necessary for interactions important for viral function, such as target receptor binding. Many Abs bind in ways that can hinder or trigger fusion-necessitated conformational changes, resulting in various neutralization mechanisms [7].

\subsubsection{HIV-1 Env Epitopes}

HIV-1 Env is present on the surfaces of virions in a closed pre-fusion conformation that includes centrally located gp120 subunits and the V1/V2 and V3 variable loops interacting about the apex of the trimer, hiding the co-receptor binding site on V3 [88]. Upon binding to the host cell receptor CD4 at the CD4 binding site (CD4bs) in the gp120 subunit, the Env protein rearranges to an open state in which the gp120s are rotated 
outwards, the V1/V2 loop is displaced to the sides of the Env trimer, and the V3 loop is exposed, allowing access to the co-receptor binding site on V3 [89-93] (Figure 3A). In the CD4-bound open conformation, a 4-stranded antiparallel bridging sheet is formed by the gp120 $\beta$-strands $\beta 20, \beta 21, \beta 2$, and $\beta 3$, the gp120 subunits swing away from the central axis and rotate slightly counter-clockwise, and the gp 41 HR1 helices become more ordered and extended [90-92]. In this conformation, the V3 loop is exposed and can then bind to the co-receptor, which is required for entry [93]. HIV-1 Env epitopes target some of these intermediate fusion conformations, in addition to the closed, pre-fusion structure.

A
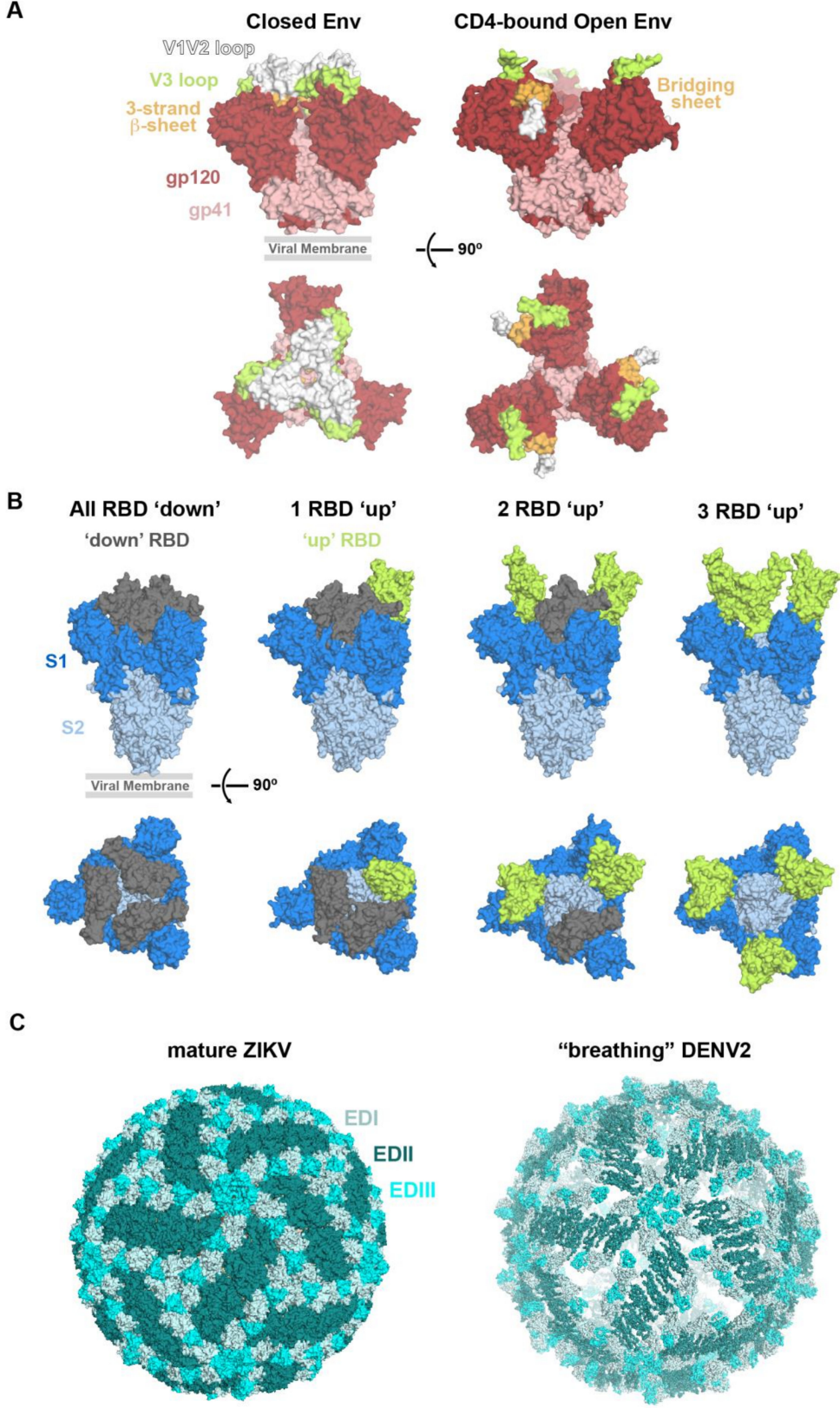

Figure 3. Conformational changes of HIV-1 Env, SARS-CoV-2 S, and ZIKV E. (A) Surface depictions of top down and side views of (left) closed, pre-fusion Env (PDB: 6UDJ) and (right) CD4-bound open conformation Env (PDB: 5VN3) highlighting the V1V2 loop (white), V3 loop (green), and 3-strand beta sheet (bright orange). Gp120= dark red, gp41 = salmon. (B) Surface depictions of side and top down views of closed, pre-fusion S with three 'down' RBDs (grey, PDB: 7K90), 1 'up' RBD (green, PDB: 7K8V), 2 'up' RBDs (7K8Y), and 3 'up' RBDs (6XCN). The location of the viral membrane is indicated in side views of viral proteins. (C) Surface depictions comparing the smooth mature ZIKV (PDB: 6CO8) and spiky "breathing" DENV2 (PDB: 3ZKO) structures. In the "breathing" DENV2 structure, EDI and EDIII of the E protein are protruding, giving the virus a "spiky" appearance, and holes are found in the surface. 
The epitopes of bNAbs often include conserved functional regions that are conformationally masked in the closed, pre-fusion structure or sterically restricted by N-linked glycans [7]. In fact, in many cases, N-glycans that occlude the protein surface of Env actually become part of the Ab epitope. HIV-1 epitope targets of bNAbs can be divided into the following categories: (1) bNAbs that bind at the apex of the trimer, specifically to the V1/V2 loops that undergo a dramatic rearrangement during host receptor engagement [94-96], (2) bNAbs against the V3-glycan patch, which includes the highly conserved GDIR motif and several N-linked glycans on and around the V3 loop [97,98], (3) CD4bs bNAbs that target the host receptor binding domain $[7,74,99],(4)$ bNAbs that only bind to Envs in a CD4-induced open state $[68,89,91],(5)$ "silent face" bNAbs that target a glycan-rich patch on the opposite face from the CD4bs on gp120 [98,100,101], (6) bNAbs that target the gp120/gp41 interface, including those that interact with the fusion peptide $[102,103]$, and (7) bNAbs that bind to the membrane proximal external region (MPER) on gp41 [104] (Figure 4A).
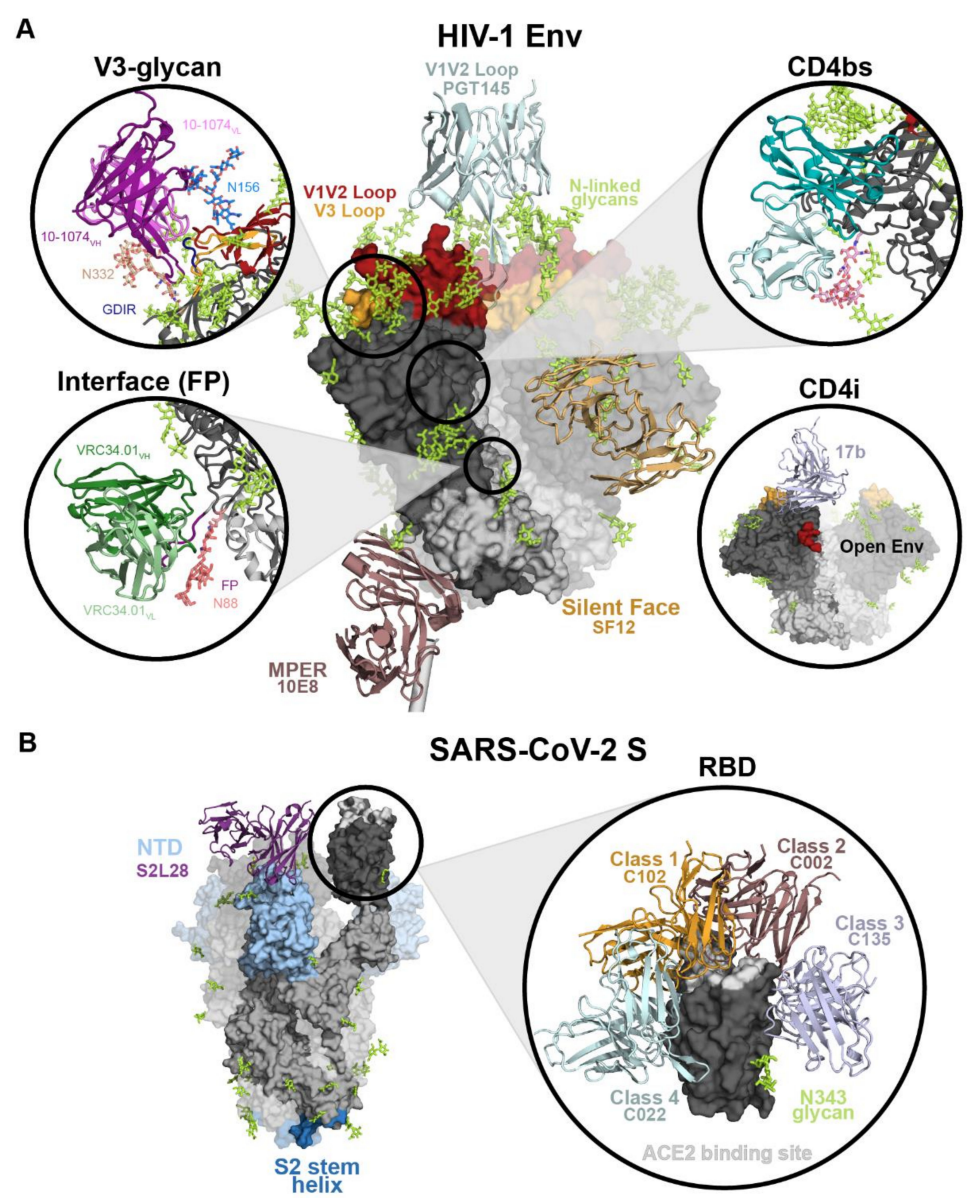

Figure 4. Neutralizing epitopes on HIV-1 Env and SARS-CoV-2 S. (A) HIV-1 Env structure (left) highlighting epitopes of representative bNAbs for each bNAb class. Env (PDB: 5T3Z) is shown as a surface with green N-linked glycans shown as sticks. Gp41 is light grey and gp120 is dark grey except for the V1V2 loop (dark red) and V3 loop (light orange). $\mathrm{V}_{\mathrm{H}} \mathrm{V}_{\mathrm{L}}$ domains of Abs binding the epitopes MPER (mauve, 10E8, PDB: 6VPX), V1V2 loop (pale cyan, PGT145, PDB: 5V8L) or Silent Face (sand, SF12, PDB: 6OKP) are shown as cartoons. Circles show details for Ab binding to the V3-glycan (10-1074, PDB: 5T3Z), interface (VRC34.01, PDB: 5I8H), CD4bs (3BNC117, PDB: 5V8L), and CD4i (17b, PDB: 7LO6). (B) SARS-CoV-2 S protein structure (left) highlighting the RBD (dark grey), S2 (blue), and NTD (light blue) Ab binding regions. $V_{H} V_{L}$ domains of Ab binding to an NTD (S2L28, PDB: 7LXX) epitope is shown as a cartoon representation. The circle (right) shows an enlarged view of the RBD surface with $\mathrm{V}_{\mathrm{H}} \mathrm{V}_{\mathrm{L}}$ domains for RBD-binding Abs shown as cartoons: Class 1 (light orange, C102, PDB: 7K8M), Class 2 (mauve, C002, PDB: 7K8S), Class 3 (pale purple, C135, PDB: 7K8Z), and Class 4 (pale cyan, C022, PDB: 7RKU). The ACE2 binding site is highlighted on the RBD in white. 
Each epitope presents a distinct landscape for bNAb binding and poses different challenges for Abs to overcome. For most epitopes, N-linked glycans on the heavilyglycosylated Env trimer sterically restrict access to conserved protein regions, and therefore bNAbs tend to include conserved N-linked glycans in the epitope and/or develop long complementary determining region (CDR) loops to penetrate through the glycan shield [7]. This is the case for V1/V2, V3, and silent face epitopes. For example, the V3-glycan patch epitope is defined by the V3 loop that is essential for co-receptor binding and several $\mathrm{N}$ linked glycans. bNAbs that target this region, including 10-1074, PGT121, and BG18, have long, 20+ amino acid CDRH3 loops that reach through the glycan patch to bind a conserved V3 motif from gp120 residues 324-327 with the sequence GDIR [97]. These bNAbs also make important contacts with conserved glycans Asn156 gp120 and Asn332 gp120. In contrast, some bNAbs against the CD4bs require short CDR loops to accommodate an N-linked glycan in that region. CD4bs bNAb 3BNC117 has a 5-residue deletion in CDRL1 that is necessary to prevent steric clashes with the Asn276 gp120 glycan and a short, 5-amino acid CDRL3 that is essential to avoid clashes with gp120 [105]. The gp120-gp41 interface epitope is composed of protein and glycan residues in both subunits. This category includes bNAbs that target the fusion peptide (FP), which are the highly conserved $\mathrm{N}$ terminal residues of gp41 responsible for burying into the host cell membrane during the fusion process of viral entry. FP bNAb VRC34.01 binds primarily to the N-terminal 8 residues of gp41 with the remainder of interactions made with Asn $88_{\text {gp } 120}$ [102]. Together, these examples demonstrate the diverse epitope landscape of the HIV-1 Env trimer and how Abs develop particular features to overcome challenges posed by the dense glycan shield.

The mode of binding for bNAbs at all epitopes has been greatly illuminated by structural biology. In particular, X-ray crystallographic and cryo-EM structures of Ab:Env complexes have been essential tools to characterize which epitope newly isolated bNAbs bind, the mode of binding implemented, and to understand the context of atypical features in the sequence such as CDR lengths. The wealth of structural data has enabled structurebased design of gp120 and SOSIP-based immunogens that seek to elicit responses to particular epitopes and design small molecule drugs.

\subsubsection{SARS-CoV-2 S Epitopes}

The SARS-CoV-2 fusion machinery is the surface protein S, which is composed of three identical subunits each containing an RBD that sits at the apex of $S$ and is attached to the rest of the subunits with a flexible hinge [14]. The RBDs are able to sample a 'down' conformation that hides the ACE2 binding site by packing it against a neighboring RBD, or an 'up' conformation, which exposes the ACE2 binding site at the tip of the RBD and is required for host receptor binding $[15,32,106]$ (Figure 3B).

Abs that recognize the RBD of the SARS-CoV-2 S protein are a vital part of the neutralizing $\mathrm{Ab}$ response to infection and vaccination because the RBD contains the binding site for ACE2. Effective neutralization by many anti-RBD Abs is due to their ability to block the RBD from binding the host ACE2 receptor. The epitopes targeted by Abs against the RBD can be organized into four simplified classes [32]. Class 1, VH3-53/VH3-63derived Abs, target epitopes overlapping with the ACE2 binding site and only bind 'up' conformation RBDs. Class 2 Abs target epitopes overlapping with the ACE2 binding site and can bind both 'up' and 'down' RBDs. Class 3 Abs target epitopes that do not overlap with the ACE2 binding site and bind both 'up' and 'down' RBDs. Finally, class 4 Abs target a cryptic surface facing the $S$ trimer interior and only bind 'up' RBDs [32] (Figure 4B).

While the anti-SARS-CoV-2 Ab landscape has primarily focused on the RBD, a growing number of neutralizing Abs that target other regions of the $\mathrm{S}$ protein are being found. Neutralizing Abs that bind to the N terminal domain (NTD) [107-109] and the S2 domain $[107,110-113]$ have been reported, indicating that the RBD is not the only site of neutralization. In addition, some of these Abs are also broadly cross-reactive to other betacoronaviruses as they target highly conserved regions of $S$ such as the class 4 cryptic epitope on the RBD [24,114-116] or the stem helix of S2 [111-113]. 


\subsubsection{ZIKV Epitopes}

The E protein of ZIKV and other flaviviruses is key for facilitating cellular entry and fusion [48]. The mature structure of ZIKV displays smooth virus particles with 180 copies of the E protein arranged as 90 dimers with icosahedral symmetry, and EDIII is thought to be responsible for binding cellular receptors [43,48,117-120]. After cellular entry through receptor-mediated endocytosis, the acidic $\mathrm{pH}$ triggers a conformational change by which the E proteins form trimers and expose the FL on EDII for membrane fusion [121-123].

Given its role in fusion, the $E$ protein is an important target of neutralizing Abs that effectively clear ZIKV, inhibit ZIKV infection in vitro, decrease vertical transmission, and are protective in ZIKV challenge in animal models [53-56,72,79,124,125] (Figure 2C). Structural characterization of Abs that bind the ZIKV E protein have revealed multiple epitopes on the three domains: (1) the conserved FL found on EDII [56,126], (2) EDIII [52-54,72,73,127], (3) multiple domains of single E protein [79,80], (4) multiple domains spanning an E protein dimer [55,60,79,125,128,129], and (5) multiple domains spanning neighboring E dimer pairs $[61,62,79,129]$. Abs against the FL in EDII compose a large portion of the response to infection, and because the FL is conserved among flaviviruses, these Abs can cross-react with different flaviviruses [56,79,124-126,130]. However, many potently-neutralizing Abs target EDIII and these Abs tend to be more specific for ZIKV than other flaviviruses [51-56,61,72,124,125,131-137] (Figure 2C).

Notably, some $\mathrm{Ab}$ epitopes characterized by crystallography are not accessible on the known cryo-EM structures of mature ZIKV [43,54,56,126] (Figure 3C). While cryo-EM structures show a static envelope, evidence suggests the $\mathrm{E}$ proteins are dynamic and sample different conformations. The phenomenon of flavivirus "breathing" may result from conformational changes of the E protein during the viral life cycle, such as during fusion. The flavivirus DENV serotype 2 (DENV2) structure showed E protein rearrangements when heated to $37^{\circ} \mathrm{C}$, providing further evidence for flavivirus breathing [47,138] (Figure 3C). However, ZIKV maintains a smooth structure at $40^{\circ} \mathrm{C}$ and its breathing conformation has not yet been determined [42].

\subsection{Somatic Hypermutation of Neutralizing Abs}

Abs evolve to neutralize antigen targets through the process of affinity maturation. This process begins when germline-encoded $B$ cell receptors interact with an antigen and receive signals from $\mathrm{T}$ cells. This activation stimulates iterative rounds of somatic hypermutation (SHM), whereby a cellular mechanism orchestrates single base pair mutations, insertions, and deletions (indels) primarily in the CDRs of Abs [139]. These mutations are random, although favorable mutations that enhance recognition of antigen are selected for in further rounds of SHM [139]. Affinity maturation can rapidly diversify the Ab repertoire, allowing for the recognition of innumerable antigens that can mutate to evade $\mathrm{Ab}$ recognition [140]. This arms race between distinct Abs and antigens has been monitored through structural biology, which can illuminate how SHM impacts the antigen:Ab interface. For different viral antigens, SHM plays different roles in overcoming infection.

In HIV-1 infection, SHM plays a major role in the creation of bNAbs. Human Abs that have undergone affinity maturation on average carry 15-20 nucleotide mutations in the variable heavy $\left(\mathrm{V}_{\mathrm{H}}\right)$ gene; however, HIV-1 bNAbs include 40-100 $\mathrm{V}_{\mathrm{H}}$ gene mutations [141]. High levels of bNAb SHM are necessary to combat a rapidly evolving antigen target in which Env mutations are selected to evade bNAb recognition. In fact, these mutations have been deemed critical for recognition and neutralization of native viral envelopes, as unmutated germline precursors of bNAbs do not usually interact with viral Envs [142]. X-ray crystallography and cryo-EM have allowed for the characterization of bNAb SHM to understand how mutated residues interact with HIV-1 Env and confer broadly neutralizing activity and potency $[7,143,144]$. Structures of Env:bNAb complexes have identified individual SHMs that are critical for neutralization activity at different epitopes and have set forth criteria for predicting the capability of newly isolated bNAbs.

Furthermore, structural biology has given context to unusual bNAb characteristics brought on by SHM; namely, framework region (FWR) mutations and indels. The FWRs of an $\mathrm{Ab}$ variable domain are the relatively constant sequences that provide a scaffold for 
the more diverse CDR loops. SHMs in FWRs are often poorly tolerated as they impair the structural integrity of the Ab [145-147]. However, HIV-1 bNAbs FWR SHM has been found to be critical for breadth and potency [145]. Analysis of crystal structures of bNAbs bound to gp120s revealed that regions of FWR SHM can directly interact with the antigen to increase the binding affinity or contribute to the structural rigidity and flexibility of a Fab for optimal binding [99,145]. HIV-1 bNAbs also contain unusually high levels of SHM indels $[73,76]$. Prior studies reporting sequences of Ab genes from memory $\mathrm{B}$ cells found between $1-3 \%$ of $\mathrm{Ab}$ genes contained indels [148]. For HIV-1 bNAbs, approximately $40 \%$ of bNAbs include indel mutations that range from 3-33 nucleotides in length $[73,76]$. Analysis of crystal structures of bNAb:gp120 complexes found that these indels are preferentially found within $10 \AA$ of the Ab:antigen interface [149]. Indels are therefore important to optimize interactions with Env, specifically to penetrate the dense glycan shield. Thus, structural biology has aided in elucidating how unusual SHM features in HIV-1 bNAbs contribute to breadth and potency.

Unlike HIV-1 bNAbs, Abs against SARS-CoV-2 S and ZIKV E protein have much lower levels of SHM and, in fact, affinity maturation via SHM is not always required to interact with their viral antigen targets $[23,54,150]$. Longitudinal studies tracking Ab evolution after SARS-CoV-2 infection found 1.3 months post-infection averages of $4.2 \mathrm{~V}_{\mathrm{H}}$ and $2.8 \mathrm{~V}_{\mathrm{L}}$ nucleotide mutations [151]. However, after 12 months past infection, SHM increased to approximately $15 \mathrm{~V}_{\mathrm{H}}$ and $8 \mathrm{~V}_{\mathrm{L}}$ nucleotide mutations [152]. Low levels of SHM have also been reported in longitudinal studies tracking ZIKV infection and comparisons of mature and germline versions of anti-ZIKV Abs [52,54,56,150,153,154]. Inferred germline Abs have been shown to be able to bind and even weakly neutralize ZIKV [52,54,153,155]. Structural analysis of Ab:antigen complexes for SARS-CoV-2 and ZIKV suggests most SHMs are found in CDR loops and contribute to the complex interface to create optimal contacts for antigen recognition $[25,32,52,54]$. For both of these viruses, the relatively low levels of SHM indicate near-germline and germline Abs are readily capable of recognizing viral antigens and maturing into potently neutralizing Abs.

\subsection{Structure-Guided Design of Vaccines, Small Molecules Inhibitors, and Ab Therapeutics}

Structural biology has played a pivotal role in characterizing the optimal human $\mathrm{Ab}$ response which vaccines and therapeutics can be designed to mimic (Figure 1). For many viruses, the ability to produce a cross reactive response either to many strains of the same virus or to different viruses in the same group is necessary for complete protection from disease, presenting a challenge for vaccine design [156]. Therefore, the structureguided development of small molecules, peptides, and protein decoys as therapeutics is a complementary strategy for treating viral infection [157].

Structural biology has allowed for the advancement of structure-based vaccine design, which is considered to be one of the current avenues most likely to eventually lead to an HIV-1 vaccine after the failure of subunit vaccines [158]. bNAbs are only elicited by a small subset of the population infected with HIV-1; even so these 'elite controllers' still never clear the virus [159]. In fact, arguably the biggest hurdle in creating an HIV-1 vaccine is eliciting an immune response that is far better than what is observed in infected people. The vast number of HIV-1 strains means a vaccine must protect against initial infection of countless distinct viral species rather than a single, or only a few, strains. Due to the inherent difficulty of eliciting bNAbs against HIV-1, some current structure-based efforts for HIV-1 vaccine design rely on structurally characterizing bNAbs in an effort to reverse engineer an immunogen that can elicit them, rather than the commonly-observed strain-specific, autologous neutralizing responses [158]. Structures of antigen:Ab complexes have allowed for the classification of Abs by their epitopes, which is necessary for the design of effective therapeutic monoclonal $\mathrm{Ab}$ cocktails [7]. In many cases, the dosing of single monoclonals is often suboptimal due to the ability of viruses to rapidly mutate. For example, in the case of HIV-1, the viral swarm inside a patient can evolve resistance mutations that make a therapy either less or not effective within days to weeks [160]. Therapeutics have also been 
designed to mimic an existing interaction by binding directly, such as CD4 mimetic drugs that bind into the CD4 pocket on gp120 [161,162]. As an alternative therapeutic approach, binding targets separate from canonical interaction sites can be used to inhibit function by preventing conformational changes, such as inhibitors directed at the HIV-1 Env fusion peptide [163].

In the case of SARS-CoV-2, which mutates at a lower frequency than HIV-1 but whose variants of concern are posing current problems, future efforts will need to focus on producing vaccines that are effective in the face of new variants $[164,165]$. Key regions of the $S$ protein are highly conserved across the subgenus of sarbecovirus coronaviruses, of which at least three others can infect human cells: SARS-CoV, SHC014, and RaTG13 [166]. Neutralizing Abs that target the S of SARS-CoV-2 and also bind and neutralize other sarbecoviruses including SARS-CoV-2 variants of concern have been identified by several groups and have been structurally characterized $[24,112-116,167,168]$, suggesting that an immunogen could be designed to produce a pan-sarbecovirus vaccine. Additionally, therapeutic $\mathrm{mAb}$ cocktails have successfully been developed for the treatment of SARSCoV-2 [169]. Therapeutics have also been designed to mimic an existing interaction by binding directly, such as ACE2-S small protein decoys [170].

For ZIKV, design of a safe vaccine is complicated due to the similarities in structures between ZIKV and other flaviviruses. Since the structure of ZIKV is similar to that of DENV, WENV and YFV [38-41], there is concern that Abs elicited during infection with one flavivirus may cross-react with, but not neutralize, other flaviviruses during a later infection. This cross-reactive $\mathrm{Ab}$ recognition may worsen symptoms due to a phenomenon termed Ab-dependent enhancement (ADE), by which Ab-bound viruses can infect cells through interactions of the $\mathrm{Fc}_{\mathrm{c}}$ regions of the bound Abs with the host $\mathrm{Fc} \gamma$ receptor, resulting in infection of cells after endocytosis of the Ab-virus complex [38,130,154,171-178]. This is of particular concern for the mosquito-borne virus DENV, since it has been shown that prior DENV or ZIKV infection that results in low or intermediate Ab titers increases the risk of worsened disease severity from a subsequent DENV infection with a different serotype [38,179-187]. However, potent neutralizing Abs against ZIKV EDIII have been identified that appear to be more specific for ZIKV than other flaviviruses, suggesting ZIKV EDIII is a potential candidate for the design of a safe vaccine [51-56,61,72,124,125,131-136]. No vaccine is yet universally available for ZIKV, although both the full E protein and individual EDIII have been investigated as potential immunogens [78,135,188-194].

\section{Conclusions}

Structural biology has allowed for a deeper understanding of the immune responses to many viruses, including HIV-1, SARS-CoV-2, and ZIKV discussed here. Mutations have been engineered that stabilize surface proteins in their pre-fusion conformations for use as starting immunogens for structure-based vaccine design and as laboratory reagents that can be used to study other aspects of the elicited humoral immune response. Structures of Abs bound to these stabilized proteins have allowed for the elucidation of neutralizing epitopes on the viral surface proteins. Additionally, such structures have increased our understanding of the role of features that Abs develop in response to antigens, such as somatic hypermutation, insertions, and deletions. For targets where whole inactivated or subunit vaccines have failed, structures of viral antigens bound to elicited Abs have facilitated alternative routes for structure-based design of vaccines, small molecules therapeutics, and $\mathrm{Ab}$ cocktails. It is through structural biology, inspired by advancements by Rosalind Franklin, that we are able to make progress toward vaccines and $\mathrm{Ab}$ treatments for the viruses we study, including HIV-1, SARS-CoV-2, and ZIKV.

\section{Methods}

Biorender.com was used to produce portions of Figures 1 and 2. All structure renderings were made using PyMOL ver. 2.5.0. or 1.7.6.4. 
Figure 4 was produced in PyMOL by aligning the HIV-1 Env or SARS-CoV-2 $\mathrm{S}$ proteins of each Fab-bound structure with the structure of the viral protein depicted in the figure (Env PDB: 5T3Z, S PDB: 7K8V). Only $\mathrm{V}_{\mathrm{H}} \mathrm{V}_{\mathrm{L}}$ domains are shown for each $\mathrm{Ab}$.

Author Contributions: M.E.A., K.-M.A.D., S.R.E., and C.A.J. wrote and edited this review article with critical reading and editing by P.J.B. All authors have read and agreed to the published version of the manuscript.

Funding: This research was supported by the National Institute of Allergy and Infectious Diseases (NIAID) Grant HIVRAD P01 AI100148, a George Mason University Fast Grant GMU.SARSCOV2, an NSF GRFP (to M.E.A.), a NIH National Research Service Award Fellowship F30AI147579 (S.R.E.), NIH National Institute of General Medical Sciences Training Grant T32-GM008042 (to S.R.E.) through the University of California, Los Angeles-California Institute of Technology Medical Scientist Training Program, and the National Institutes of Health (NIH) Grant AI138938. This work was supported, in whole or in part, by the Bill \& Melinda Gates Foundation (grant INV-002143). Under the grant conditions of the Foundation, a Creative Commons Attribution 4.0 Generic License has already been assigned to the Author Accepted Manuscript version that might arise from this submission.

Institutional Review Board Statement: Not applicable.

Informed Consent Statement: Not applicable.

Acknowledgments: We would like to thank members of the Bjorkman laboratory for helpful discussions; the Caltech Merkin Institute for Translational Research for resources that enable our work; the Caltech Beckman Institute Resource Center for Transmission Electron Microscopy for support in cryo-EM projects; the Gordon and Betty Moore and Beckman Foundations for gifts to support the Molecular Observatory at Caltech, which provides aid for protein crystallization; and the Stanford Synchrotron Radiation Lightsource (SSRL), which provides data collection capabilities for X-ray crystallography. Finally, we are grateful for Rosalind Franklin's contributions to structural biology and for her brazen career as a female scientist that continues to embolden researchers, especially women.

Conflicts of Interest: The authors declare no conflict of interest for this work.

\section{References}

1. Creager, A.N.H.; Morgan, G.J. After the Double Helix: Rosalind Franklin's Research on Tobacco Mosaic Virus. Isis 2008, 99, 239-272. [CrossRef] [PubMed]

2. Franklin, R.E.; Klug, A. The Nature of the Helical Groove on the Tobacco Mosaic Virus Particle X-Ray Diffraction Studies. Biochim. Biophys. Acta 1956, 19, 403-416. [CrossRef]

3. Franklin, R.E.; Holmes, K.C. The Helical Arrangement of the Protein Sub-Units in Tobacco Mosaic Virus. Biochim. Biophys. Acta 1956, 21, 405-406. [CrossRef]

4. Franklin, R.E. X-Ray Diffraction Studies of Cucumber Virus 4 and Three Strains of Tobacco Mosaic Virus. Biochim. Biophys. Acta 1956, 19, 203-211. [CrossRef]

5. Franklin, R.E. Structure of Tobacco Mosaic Virus: Location of the Ribonucleic Acid in the Tobacco Mosaic Virus Particle. Nature 1956, 177, 928-930. [CrossRef]

6. Global HIV \& AIDS Statistics. Available online: Https://Www.Unaids.Org/En/Resources/Fact-Sheet (accessed on 13 September 2021).

7. West, A.P., Jr.; Scharf, L.; Scheid, J.F.; Klein, F.; Bjorkman, P.J.; Nussenzweig, M.C. Structural Insights on the Role of Antibodies in HIV-1 Vaccine and Therapy. Cell 2014, 156, 633-648. [CrossRef]

8. Gray, E.S.; Madiga, M.C.; Hermanus, T.; Moore, P.L.; Wibmer, C.K.; Tumba, N.L.; Werner, L.; Mlisana, K.; Sibeko, S.; Williamson, C.; et al. The Neutralization Breadth of HIV-1 Develops Incrementally over Four Years and Is Associated with CD4+ T Cell Decline and High Viral Load during Acute Infection. J. Virol. 2011, 85, 4828-4840. [CrossRef]

9. Sather, D.N.; Armann, J.; Ching, L.K.; Mavrantoni, A.; Sellhorn, G.; Caldwell, Z.; Yu, X.; Wood, B.; Self, S.; Kalams, S.; et al. Factors Associated with the Development of Cross-Reactive Neutralizing Antibodies during Human Immunodeficiency Virus Type 1 Infection. J. Virol. 2009, 83, 757-769. [CrossRef]

10. Doria-Rose, N.A.; Klein, R.M.; Manion, M.M.; O’Dell, S.; Phogat, A.; Chakrabarti, B.; Hallahan, C.W.; Migueles, S.A.; Wrammert, J.; Ahmed, R.; et al. Frequency and Phenotype of Human Immunodeficiency Virus Envelope-Specific B Cells from Patients with Broadly Cross-Neutralizing Antibodies. J. Virol. 2009, 83, 188-199. [CrossRef]

11. COVID-19 Map. Available online: https:/ / coronavirus.jhu.edu/map.html (accessed on 13 September 2021).

12. Hoffmann, M.; Kleine-Weber, H.; Schroeder, S.; Krüger, N.; Herrler, T.; Erichsen, S.; Schiergens, T.S.; Herrler, G.; Wu, N.-H.; Nitsche, A.; et al. SARS-CoV-2 Cell Entry Depends on ACE2 and TMPRSS2 and Is Blocked by a Clinically Proven Protease Inhibitor. Cell 2020, 181, 271-280.e8. [CrossRef] 
13. Lan, J.; Ge, J.; Yu, J.; Shan, S.; Zhou, H.; Fan, S.; Zhang, Q.; Shi, X.; Wang, Q.; Zhang, L.; et al. Structure of the SARS-CoV-2 Spike Receptor-Binding Domain Bound to the ACE2 Receptor. Nature 2020, 581, 215-220. [CrossRef]

14. Wrapp, D.; Wang, N.; Corbett, K.S.; Goldsmith, J.A.; Hsieh, C.-L.; Abiona, O.; Graham, B.S.; McLellan, J.S. Cryo-EM Structure of the 2019-NCoV Spike in the Prefusion Conformation. Science 2020, 367, 1260-1263. [CrossRef]

15. Walls, A.C.; Park, Y.-J.; Tortorici, M.A.; Wall, A.; McGuire, A.T.; Veesler, D. Structure, Function, and Antigenicity of the SARS-CoV-2 Spike Glycoprotein. Cell 2020, 181, 281-292.e6. [CrossRef]

16. Kirchdoerfer, R.N.; Cottrell, C.A.; Wang, N.; Pallesen, J.; Yassine, H.M.; Turner, H.L.; Corbett, K.S.; Graham, B.S.; McLellan, J.S.; Ward, A.B. Pre-Fusion Structure of a Human Coronavirus Spike Protein. Nature 2016, 531, 118-121. [CrossRef]

17. Yuan, Y.; Cao, D.; Zhang, Y.; Ma, J.; Qi, J.; Wang, Q.; Lu, G.; Wu, Y.; Yan, J.; Shi, Y.; et al. Cryo-EM Structures of MERS-CoV and SARS-CoV Spike Glycoproteins Reveal the Dynamic Receptor Binding Domains. Nat. Commun. 2017, 8, 15092. [CrossRef]

18. Li, Z.; Tomlinson, A.C.; Wong, A.H.; Zhou, D.; Desforges, M.; Talbot, P.J.; Benlekbir, S.; Rubinstein, J.L.; Rini, J.M. The Human Coronavirus HCoV-229E S-Protein Structure and Receptor Binding. eLife 2019, 8, e51230. [CrossRef]

19. Walls, A.C.; Tortorici, M.A.; Bosch, B.-J.; Frenz, B.; Rottier, P.J.M.; DiMaio, F.; Rey, F.A.; Veesler, D. Cryo-Electron Microscopy Structure of a Coronavirus Spike Glycoprotein Trimer. Nature 2016, 531, 114-117. [CrossRef]

20. Roy, S.; Jaiswar, A.; Sarkar, R. Dynamic Asymmetry Exposes 2019-NCoV Prefusion Spike. J. Phys. Chem. Lett. 2020, 11, 7021-7027. [CrossRef]

21. Brouwer, P.J.M.; Caniels, T.G.; Straten, K.; van der Snitselaar, J.L.; Aldon, Y.; Bangaru, S.; Torres, J.L.; Okba, N.M.A.; Claireaux, M.; Kerster, G.; et al. Potent Neutralizing Antibodies from COVID-19 Patients Define Multiple Targets of Vulnerability. Science 2020, 369, 643-650. [CrossRef]

22. Cao, Y.; Su, B.; Guo, X.; Sun, W.; Deng, Y.; Bao, L.; Zhu, Q.; Zhang, X.; Zheng, Y.; Geng, C.; et al. Potent Neutralizing Antibodies against SARS-CoV-2 Identified by High-Throughput Single-Cell Sequencing of Convalescent Patients' B Cells. Cell 2020, 182, 73-84.e16. [CrossRef]

23. Kreer, C.; Zehner, M.; Weber, T.; Ercanoglu, M.S.; Gieselmann, L.; Rohde, C.; Halwe, S.; Korenkov, M.; Schommers, P.; Vanshylla, K.; et al. Longitudinal Isolation of Potent Near-Germline SARS-CoV-2-Neutralizing Antibodies from COVID-19 Patients. Cell 2020, 182, 843-854.e12. [CrossRef]

24. Liu, H.; Wu, N.C.; Yuan, M.; Bangaru, S.; Torres, J.L.; Caniels, T.G.; van Schooten, J.; Zhu, X.; Lee, C.-C.D.; Brouwer, P.J.M.; et al. Cross-Neutralization of a SARS-CoV-2 Antibody to a Functionally Conserved Site Is Mediated by Avidity. Immunity 2020, 53, 1272-1280.e5. [CrossRef] [PubMed]

25. Robbiani, D.F.; Gaebler, C.; Muecksch, F.; Lorenzi, J.C.C.; Wang, Z.; Cho, A.; Agudelo, M.; Barnes, C.O.; Gazumyan, A.; Finkin, S.; et al. Convergent Antibody Responses to SARS-CoV-2 in Convalescent Individuals. Nature 2020, 584, 437-442. [CrossRef] [PubMed]

26. Rogers, T.F.; Zhao, F.; Huang, D.; Beutler, N.; Burns, A.; He, W.; Limbo, O.; Smith, C.; Song, G.; Woehl, J.; et al. Isolation of Potent SARS-CoV-2 Neutralizing Antibodies and Protection from Disease in a Small Animal Model. Science 2020, 369, 956-963. [CrossRef]

27. Seydoux, E.; Homad, L.J.; MacCamy, A.J.; Parks, K.R.; Hurlburt, N.K.; Jennewein, M.F.; Akins, N.R.; Stuart, A.B.; Wan, Y.-H.; Feng, J.; et al. Analysis of a SARS-CoV-2-Infected Individual Reveals Development of Potent Neutralizing Antibodies with Limited Somatic Mutation. Immunity 2020, 53, 98-105.e5. [CrossRef] [PubMed]

28. Shi, R.; Shan, C.; Duan, X.; Chen, Z.; Liu, P.; Song, J.; Song, T.; Bi, X.; Han, C.; Wu, L.; et al. A Human Neutralizing Antibody Targets the Receptor-Binding Site of SARS-CoV-2. Nature 2020, 584, 120-124. [CrossRef] [PubMed]

29. Zost, S.J.; Gilchuk, P.; Case, J.B.; Binshtein, E.; Chen, R.E.; Nkolola, J.P.; Schäfer, A.; Reidy, J.X.; Trivette, A.; Nargi, R.S.; et al. Potently Neutralizing and Protective Human Antibodies against SARS-CoV-2. Nature 2020, 584, 443-449. [CrossRef]

30. Zost, S.J.; Gilchuk, P.; Chen, R.E.; Case, J.B.; Reidy, J.X.; Trivette, A.; Nargi, R.S.; Sutton, R.E.; Suryadevara, N.; Chen, E.C.; et al. Rapid Isolation and Profiling of a Diverse Panel of Human Monoclonal Antibodies Targeting the SARS-CoV-2 Spike Protein. Nat. Med. 2020, 26, 1422-1427. [CrossRef]

31. Pinto, D.; Park, Y.-J.; Beltramello, M.; Walls, A.C.; Tortorici, M.A.; Bianchi, S.; Jaconi, S.; Culap, K.; Zatta, F.; De Marco, A.; et al. Cross-Neutralization of SARS-CoV-2 by a Human Monoclonal SARS-CoV Antibody. Nature 2020, 583, 290-295. [CrossRef]

32. Barnes, C.O.; Jette, C.A.; Abernathy, M.E.; Dam, K.-M.A.; Esswein, S.R.; Gristick, H.B.; Malyutin, A.G.; Sharaf, N.G.; HueyTubman, K.E.; Lee, Y.E.; et al. SARS-CoV-2 Neutralizing Antibody Structures Inform Therapeutic Strategies. Nature 2020, 588, 682-687. [CrossRef]

33. Barnes, C.O.; West, A.P.; Huey-Tubman, K.E.; Hoffmann, M.A.G.; Sharaf, N.G.; Hoffman, P.R.; Koranda, N.; Gristick, H.B.; Gaebler, C.; Muecksch, F.; et al. Structures of Human Antibodies Bound to SARS-CoV-2 Spike Reveal Common Epitopes and Recurrent Features of Antibodies. Cell 2020, 182, 828-842.e16. [CrossRef]

34. Suy, A.; Sulleiro, E.; Rodo, C.; Vazquez, E.; Bocanegra, C.; Molina, I.; Esperalba, J.; Sanchez-Seco, M.P.; Boix, H.; Pumarola, T.; et al. Prolonged Zika Virus Viremia during Pregnancy. N. Engl. J. Med. 2016, 375, 2611-2613. [CrossRef]

35. Brasil, P.; Pereira, J.P.; Moreira, M.E.; Ribeiro Nogueira, R.M.; Damasceno, L.; Wakimoto, M.; Rabello, R.S.; Valderramos, S.G.; Halai, U.A.; Salles, T.S.; et al. Zika Virus Infection in Pregnant Women in Rio de Janeiro. N. Engl. J. Med. 2016, 375, $2321-2334$. [CrossRef]

36. Coyne, C.B.; Lazear, H.M. Zika Virus-Reigniting the TORCH. Nat. Rev. Microbiol. 2016, 14, 707-715. [CrossRef] 
37. Mlakar, J.; Korva, M.; Tul, N.; Popović, M.; Poljšak-Prijatelj, M.; Mraz, J.; Kolenc, M.; Resman Rus, K.; Vesnaver Vipotnik, T.; Fabjan Vodušek, V.; et al. Zika Virus Associated with Microcephaly. Available online: https://www.nejm.org/doi/10.1056/ NEJMoa1600651 (accessed on 18 June 2021).

38. Heinz, F.X.; Stiasny, K. The Antigenic Structure of Zika Virus and Its Relation to Other Flaviviruses: Implications for Infection and Immunoprophylaxis. Microbiol. Mol. Biol. Rev. 2017, 81, e00055-16. [CrossRef]

39. Chang, H.-H.; Huber, R.G.; Bond, P.J.; Grad, Y.H.; Camerini, D.; Maurer-Stroh, S.; Lipsitch, M. Systematic Analysis of Protein Identity between Zika Virus and Other Arthropod-Borne Viruses. Bull. World Health Organ. 2017, 95, 517-525I. [CrossRef]

40. da Fonseca, N.J.; Lima Afonso, M.Q.; Pedersolli, N.G.; de Oliveira, L.C.; Andrade, D.S.; Bleicher, L. Sequence, Structure and Function Relationships in Flaviviruses as Assessed by Evolutive Aspects of Its Conserved Non-Structural Protein Domains. Biochem. Biophys. Res. Commun. 2017, 492, 565-571. [CrossRef]

41. Ye, Q.; Liu, Z.-Y.; Han, J.-F.; Jiang, T.; Li, X.-F.; Qin, C.-F. Genomic Characterization and Phylogenetic Analysis of Zika Virus Circulating in the Americas. Infect. Genet. Evol. 2016, 43, 43-49. [CrossRef]

42. Kostyuchenko, V.A.; Lim, E.X.; Zhang, S.; Fibriansah, G.; Ng, T.S.; Ooi, J.S.; Shi, J.; Lok, S.M. Structure of the Thermally Stable Zika Virus. Nature 2016, 533, 425-428. [CrossRef]

43. Sirohi, D.; Chen, Z.; Sun, L.; Klose, T.; Pierson, T.C.; Rossmann, M.G.; Kuhn, R.J. The 3.8 A Resolution Cryo-EM Structure of Zika Virus. Science 2016, 352, 467-470. [CrossRef]

44. Pierson, T.C.; Diamond, M.S. The Emergence of Zika Virus and Its New Clinical Syndromes. Nature 2018, 560, 573-581. [CrossRef] [PubMed]

45. Kuhn, R.J.; Dowd, K.A.; Beth Post, C.; Pierson, T.C. Shake, Rattle, and Roll: Impact of the Dynamics of Flavivirus Particles on Their Interactions with the Host. Virology 2015, 479-480, 508-517. [CrossRef] [PubMed]

46. Dowd, K.A.; DeMaso, C.R.; Pierson, T.C. Genotypic Differences in Dengue Virus Neutralization Are Explained by a Single Amino Acid Mutation That Modulates Virus Breathing. MBio 2015, 6, e01559-15. [CrossRef] [PubMed]

47. Fibriansah, G.; Ng, T.-S.; Kostyuchenko, V.A.; Lee, J.; Lee, S.; Wang, J.; Lok, S.-M. Structural Changes in Dengue Virus When Exposed to a Temperature of $37^{\circ}$ C. J. Virol. 2013, 87, 7585-7592. [CrossRef] [PubMed]

48. Mukhopadhyay, S.; Kuhn, R.J.; Rossmann, M.G. A Structural Perspective of the Flavivirus Life Cycle. Nat. Rev. Microbiol. 2005, 3, 13-22. [CrossRef] [PubMed]

49. Yu, I.M.; Zhang, W.; Holdaway, H.A.; Li, L.; Kostyuchenko, V.A.; Chipman, P.R.; Kuhn, R.J.; Rossmann, M.G.; Chen, J. Structure of the Immature Dengue Virus at Low PH Primes Proteolytic Maturation. Science 2008, 319, 1834-1837. [CrossRef]

50. Kuhn, R.J.; Zhang, W.; Rossmann, M.G.; Pletnev, S.V.; Corver, J.; Lenches, E.; Jones, C.T.; Mukhopadhyay, S.; Chipman, P.R.; Strauss, E.G.; et al. Structure of Dengue Virus: Implications for Flavivirus Organization, Maturation, and Fusion. Cell 2002, 108, 717-725. [CrossRef]

51. Pierson, T.C.; Fremont, D.H.; Kuhn, R.J.; Diamond, M.S. Structural Insights into the Mechanisms of Antibody-Mediated Neutralization of Flavivirus Infection: Implications for Vaccine Development. Cell Host Microbe 2008, 4, 229-238. [CrossRef]

52. Esswein, S.R.; Gristick, H.B.; Jurado, A.; Peace, A.; Keeffe, J.R.; Lee, Y.E.; Voll, A.V.; Saeed, M.; Nussenzweig, M.C.; Rice, C.M.; et al. Structural Basis for Zika Envelope Domain III Recognition by a Germline Version of a Recurrent Neutralizing Antibody. Proc. Natl. Acad. Sci. USA 2020, 117, 9865-9875. [CrossRef]

53. Keeffe, J.R.; Van Rompay, K.K.A.; Olsen, P.C.; Wang, Q.; Gazumyan, A.; Azzopardi, S.A.; Schaefer-Babajew, D.; Lee, Y.E.; Stuart, J.B.; Singapuri, A.; et al. A Combination of Two Human Monoclonal Antibodies Prevents Zika Virus Escape Mutations in Non-Human Primates. Cell Rep. 2018, 25, 1385-1394.e7. [CrossRef]

54. Robbiani, D.F.; Bozzacco, L.; Keeffe, J.R.; Khouri, R.; Olsen, P.C.; Gazumyan, A.; Schaefer-Babajew, D.; Avila-Rios, S.; Nogueira, L.; Patel, R.; et al. Recurrent Potent Human Neutralizing Antibodies to Zika Virus in Brazil and Mexico. Cell 2017, 169, 597-609.e11. [CrossRef]

55. Barba-Spaeth, G.; Dejnirattisai, W.; Rouvinski, A.; Vaney, M.C.; Medits, I.; Sharma, A.; Simon-Loriere, E.; Sakuntabhai, A.; Cao-Lormeau, V.M.; Haouz, A.; et al. Structural Basis of Potent Zika-Dengue Virus Antibody Cross-Neutralization. Nature 2016, 536, 48-53. [CrossRef]

56. Dai, L.; Song, J.; Lu, X.; Deng, Y.Q.; Musyoki, A.M.; Cheng, H.; Zhang, Y.; Yuan, Y.; Song, H.; Haywood, J.; et al. Structures of the Zika Virus Envelope Protein and Its Complex with a Flavivirus Broadly Protective Antibody. Cell Host Microbe 2016, 19, 696-704. [CrossRef]

57. Prasad, V.M.; Miller, A.S.; Klose, T.; Sirohi, D.; Buda, G.; Jiang, W.; Kuhn, R.J.; Rossmann, M.G. Structure of the Immature Zika Virus at 9 A Resolution. Nat. Struct. Mol. Biol. 2017, 24, 184-186. [CrossRef]

58. Sevvana, M.; Long, F.; Miller, A.S.; Klose, T.; Buda, G.; Sun, L.; Kuhn, R.J.; Rossmann, M.G. Refinement and Analysis of the Mature Zika Virus Cryo-EM Structure at $3.1 \AA$ Resolution. Structure 2018, 26, 1169-1177.e3. [CrossRef]

59. Morrone, S.R.; Chew, V.S.Y.; Lim, X.-N.; Ng, T.-S.; Kostyuchenko, V.A.; Zhang, S.; Wirawan, M.; Chew, P.-L.; Lee, J.; Tan, J.L.; et al. High Flavivirus Structural Plasticity Demonstrated by a Non-Spherical Morphological Variant. Nat. Commun. 2020, 11, 3112. [CrossRef]

60. Tyagi, A.; Ahmed, T.; Shi, J.; Bhushan, S. A Complex between the Zika Virion and the Fab of a Broadly Cross-Reactive Neutralizing Monoclonal Antibody Revealed by Cryo-EM and Single Particle Analysis at 4.1 Å Resolution. J. Struct. Biol. X 2020, $4,100028$. [CrossRef] 
61. Zhang, S.; Loy, T.; Ng, T.-S.; Lim, X.-N.; Chew, S.-Y.V.; Tan, T.Y.; Xu, M.; Kostyuchenko, V.A.; Tukijan, F.; Shi, J.; et al. A Human Antibody Neutralizes Different Flaviviruses by Using Different Mechanisms. Cell Rep. 2020, 31, 107584. [CrossRef]

62. Long, F.; Doyle, M.; Fernandez, E.; Miller, A.S.; Klose, T.; Sevvana, M.; Bryan, A.; Davidson, E.; Doranz, B.J.; Kuhn, R.J.; et al. Structural Basis of a Potent Human Monoclonal Antibody against Zika Virus Targeting a Quaternary Epitope. Proc. Natl. Acad. Sci. USA 2019, 116, 1591-1596. [CrossRef]

63. Jiang, W.; Tang, L. Atomic Cryo-EM Structures of Viruses. Curr. Opin. Struct. Biol. 2017, 46, 122-129. [CrossRef]

64. Luque, D.; Castón, J.R. Cryo-Electron Microscopy for the Study of Virus Assembly. Nat. Chem. Biol. 2020, 16, 231-239. [CrossRef]

65. Grünewald, K.; Cyrklaff, M. Structure of Complex Viruses and Virus-Infected Cells by Electron Cryo Tomography. Curr. Opin. Microbiol. 2006, 9, 437-442. [CrossRef]

66. Klasse, P.J.; Depetris, R.S.; Pejchal, R.; Julien, J.-P.; Khayat, R.; Lee, J.H.; Marozsan, A.J.; Cupo, A.; Cocco, N.; Korzun, J.; et al. Influences on Trimerization and Aggregation of Soluble, Cleaved HIV-1 SOSIP Envelope Glycoprotein. J. Virol. 2013, 87, 9873-9885. [CrossRef]

67. Hsieh, C.-L.; Goldsmith, J.A.; Schaub, J.M.; DiVenere, A.M.; Kuo, H.-C.; Javanmardi, K.; Le, K.C.; Wrapp, D.; Lee, A.G.; Liu, Y.; et al. Structure-Based Design of Prefusion-Stabilized SARS-CoV-2 Spikes. Science 2020, 369, 1501-1505. [CrossRef]

68. Kwong, P.D.; Wyatt, R.; Robinson, J.; Sweet, R.W.; Sodroski, J.; Hendrickson, W.A. Structure of an HIV Gp120 Envelope Glycoprotein in Complex with the CD4 Receptor and a Neutralizing Human Antibody. Nature 1998, 393, 648-659. [CrossRef]

69. Diskin, R.; Marcovecchio, P.M.; Bjorkman, P.J. Structure of a Clade C HIV-1 Gp120 Bound to CD4 and CD4-Induced Antibody Reveals Anti-CD4 Polyreactivity. Nat. Publ. Group 2010, 17, 608-613. [CrossRef]

70. Li, F. Structure of SARS Coronavirus Spike Receptor-Binding Domain Complexed with Receptor. Science 2005, 309, 1864-1868. [CrossRef]

71. Du, L.; Kou, Z.; Ma, C.; Tao, X.; Wang, L.; Zhao, G.; Chen, Y.; Yu, F.; Tseng, C.-T.K.; Zhou, Y.; et al. A Truncated Receptor-Binding Domain of MERS-CoV Spike Protein Potently Inhibits MERS-CoV Infection and Induces Strong Neutralizing Antibody Responses: Implication for Developing Therapeutics and Vaccines. PLoS ONE 2013, 8, e81587. [CrossRef]

72. Zhao, H.; Fernandez, E.; Dowd, K.A.; Speer, S.D.; Platt, D.J.; Gorman, M.J.; Govero, J.; Nelson, C.A.; Pierson, T.C.; Diamond, M.S.; et al. Structural Basis of Zika Virus-Specific Antibody Protection. Cell 2016, 166, 1016-1027. [CrossRef]

73. Zhao, H.; Xu, L.; Bombardi, R.; Nargi, R.; Deng, Z.; Errico, J.M.; Nelson, C.A.; Dowd, K.A.; Pierson, T.C.; Crowe, J.E.; et al. Mechanism of Differential Zika and Dengue Virus Neutralization by a Public Antibody Lineage Targeting the DIII Lateral Ridge. J. Exp. Med. 2020, 217, 1016-1027. [CrossRef]

74. Zhou, T.; Zhu, J.; Wu, X.; Moquin, S.; Zhang, B.; Acharya, P.; Georgiev, I.S.; Altae-Tran, H.R.; Chuang, G.-Y.; Joyce, M.G.; et al. Multidonor Analysis Reveals Structural Elements, Genetic Determinants, and Maturation Pathway for HIV-1 Neutralization by VRC01-Class Antibodies. Immunity 2013, 39, 245-258. [CrossRef] [PubMed]

75. Sanders, R.W.; Moore, J.P. Virus Vaccines: Proteins Prefer Prolines. Cell Host Microbe 2021, 29, 327-333. [CrossRef] [PubMed]

76. Qiao, H.; Pelletier, S.L.; Hoffman, L.; Hacker, J.; Armstrong, R.T.; White, J.M. Specific Single or Double Proline Substitutions in the "Spring-Loaded" Coiled-Coil Region of the Influenza Hemagglutinin Impair or Abolish Membrane Fusion Activity. J. Cell Biol. 1998, 141, 1335-1347. [CrossRef]

77. Sanders, R.W.; Vesanen, M.; Schuelke, N.; Master, A.; Schiffner, L.; Kalyanaraman, R.; Paluch, M.; Berkhout, B.; Maddon, P.J.; Olson, W.C.; et al. Stabilization of the Soluble, Cleaved, Trimeric Form of the Envelope Glycoprotein Complex of Human Immunodeficiency Virus Type 1. J. Virol. 2002, 76, 8875-8889. [CrossRef] [PubMed]

78. Qu, P.; Zhang, W.; Li, D.; Zhang, C.; Liu, Q.; Zhang, X.; Wang, X.; Dai, W.; Xu, Y.; Leng, Q.; et al. Insect Cell-Produced Recombinant Protein Subunit Vaccines Protect against Zika Virus Infection. Antiviral Res. 2018, 154, 97-103. [CrossRef]

79. Wang, Q.; Yang, H.; Liu, X.; Dai, L.; Ma, T.; Qi, J.; Wong, G.; Peng, R.; Liu, S.; Li, J.; et al. Molecular Determinants of Human Neutralizing Antibodies Isolated from a Patient Infected with Zika Virus. Sci. Transl. Med. 2016, 8, 369ra179. [CrossRef]

80. Dussupt, V.; Sankhala, R.S.; Gromowski, G.D.; Donofrio, G.; De La Barrera, R.A.; Larocca, R.A.; Zaky, W.; Mendez-Rivera, L.; Choe, M.; Davidson, E.; et al. Potent Zika and Dengue Cross-Neutralizing Antibodies Induced by Zika Vaccination in a Dengue-Experienced Donor. Nat. Med. 2020, 26, 228-235. [CrossRef]

81. Slon Campos, J.L.; Marchese, S.; Rana, J.; Mossenta, M.; Poggianella, M.; Bestagno, M.; Burrone, O.R. Temperature-Dependent Folding Allows Stable Dimerization of Secretory and Virus-Associated E Proteins of Dengue and Zika Viruses in Mammalian Cells. Sci. Rep. 2017, 7, 966. [CrossRef]

82. Harrison, S.C. Viral Membrane Fusion. Virology 2015, 479-480, 498-507. [CrossRef]

83. Ackerman, M.E.; Mikhailova, A.; Brown, E.P.; Dowell, K.G.; Walker, B.D.; Bailey-Kellogg, C.; Suscovich, T.J.; Alter, G. Polyfunctional HIV-Specific Antibody Responses Are Associated with Spontaneous HIV Control. PLoS Pathog. 2016, 12, e1005315. [CrossRef]

84. Gunn, B.M.; Yu, W.-H.; Karim, M.M.; Brannan, J.M.; Herbert, A.S.; Wec, A.Z.; Halfmann, P.J.; Fusco, M.L.; Schendel, S.L.; Gangavarapu, K.; et al. A Role for Fc Function in Therapeutic Monoclonal Antibody-Mediated Protection against Ebola Virus. Cell Host Microbe 2018, 24, 221-233.e5. [CrossRef]

85. Lu, L.L.; Suscovich, T.J.; Fortune, S.M.; Alter, G. Beyond Binding: Antibody Effector Functions in Infectious Diseases. Nat. Rev. Immunol. 2018, 18, 46-61. [CrossRef]

86. Saphire, E.O.; Schendel, S.L.; Gunn, B.M.; Milligan, J.C.; Alter, G. Antibody-Mediated Protection against Ebola Virus. Nat. Immunol. 2018, 19, 1169-1178. [CrossRef] 
87. White, J.M.; Delos, S.E.; Brecher, M.; Schornberg, K. Structures and Mechanisms of Viral Membrane Fusion Proteins: Multiple Variations on a Common Theme. Crit. Rev. Biochem. Mol. Biol. 2008, 43, 189-219. [CrossRef]

88. Ward, A.B.; Wilson, I.A. The HIV-1 Envelope Glycoprotein Structure: Nailing down a Moving Target. Immunol. Rev. 2017, 275, 21-32. [CrossRef]

89. Ozorowski, G.; Pallesen, J.; de Val, N.; Lyumkis, D.; Cottrell, C.A.; Torres, J.L.; Copps, J.; Stanfield, R.L.; Cupo, A.; Pugach, P.; et al. Open and Closed Structures Reveal Allostery and Pliability in the HIV-1 Envelope Spike. Nature 2017, 547, 360-363. [CrossRef]

90. Wang, H.; Barnes, C.O.; Yang, Z.; Nussenzweig, M.C.; Bjorkman, P.J. Partially Open HIV-1 Envelope Structures Exhibit Conformational Changes Relevant for Coreceptor Binding and Fusion. Cell Host Microbe 2018, 24, 579-592.e4. [CrossRef]

91. Yang, Z.; Wang, H.; Liu, A.Z.; Gristick, H.B.; Bjorkman, P.J. Asymmetric Opening of HIV-1 Env Bound to CD4 and a CoreceptorMimicking Antibody. Nat. Struct. Mol. Biol. 2019, 26, 1167-1175. [CrossRef]

92. Wang, H.; Cohen, A.A.; Galimidi, R.P.; Gristick, H.B.; Jensen, G.J.; Bjorkman, P.J. Cryo-EM Structure of a CD4-Bound Open HIV-1 Envelope Trimer Reveals Structural Rearrangements of the Gp120 V1V2 Loop. Proc. Natl. Acad. Sci. USA 2016, 113, E7151-E7158. [CrossRef]

93. Alkhatib, G. The Biology of CCR5 and CXCR4. Curr. Opin. HIV AIDS 2009, 4, 96-103. [CrossRef]

94. Lee, J.H.; Andrabi, R.; Su, C.-Y.; Yasmeen, A.; Julien, J.-P.; Kong, L.; Wu, N.C.; McBride, R.; Sok, D.; Pauthner, M.; et al. A Broadly Neutralizing Antibody Targets the Dynamic HIV Envelope Trimer Apex via a Long, Rigidified, and Anionic $\beta$-Hairpin Structure. Immunity 2017, 46, 690-702. [CrossRef] [PubMed]

95. Gorman, J.; Soto, C.; Yang, M.M.; Davenport, T.M.; Guttman, M.; Bailer, R.T.; Chambers, M.; Chuang, G.-Y.; DeKosky, B.J.; Doria-Rose, N.A.; et al. Structures of HIV-1 Env V1V2 with Broadly Neutralizing Antibodies Reveal Commonalities That Enable Vaccine Design. Nat. Struct. Mol. Biol. 2016, 23, 81-90. [CrossRef] [PubMed]

96. Walker, L.M.; Phogat, S.K.; Chan-Hui, P.-Y.; Wagner, D.; Phung, P.; Goss, J.L.; Wrin, T.; Simek, M.D.; Fling, S.; Mitcham, J.L.; et al. Broad and Potent Neutralizing Antibodies from an African Donor Reveal a New HIV-1 Vaccine Target. Science 2009, 326, 285-289. [CrossRef] [PubMed]

97. Fera, D.; Lee, M.S.; Wiehe, K.; Meyerhoff, R.R.; Piai, A.; Bonsignori, M.; Aussedat, B.; Walkowicz, W.E.; Ton, T.; Zhou, J.O.; et al. HIV Envelope V3 Region Mimic Embodies Key Features of a Broadly Neutralizing Antibody Lineage Epitope. Nat. Commun. 2018, 9, 1111. [CrossRef]

98. Barnes, C.O.; Gristick, H.B.; Freund, N.T.; Escolano, A.; Lyubimov, A.Y.; Hartweger, H.; West, A.P.; Cohen, A.E.; Nussenzweig, M.C.; Bjorkman, P.J. Structural Characterization of a Highly-Potent V3-Glycan Broadly Neutralizing Antibody Bound to Natively-Glycosylated HIV-1 Envelope. Nat. Commun. 2018, 9, 1251. [CrossRef]

99. Scheid, J.F.; Mouquet, H.; Ueberheide, B.; Diskin, R.; Klein, F.; Oliveira, T.Y.K.; Pietzsch, J.; Fenyo, D.; Abadir, A.; Velinzon, K.; et al. Sequence and Structural Convergence of Broad and Potent HIV Antibodies That Mimic CD4 Binding. Science 2011, 333, $1633-1637$. [CrossRef]

100. Schoofs, T.; Barnes, C.O.; Suh-Toma, N.; Golijanin, J.; Schommers, P.; Gruell, H.; West, A.P.; Bach, F.; Lee, Y.E.; Nogueira, L.; et al. Broad and Potent Neutralizing Antibodies Recognize the Silent Face of the HIV Envelope. Immunity 2019, 50, 1513-1529.e9. [CrossRef]

101. Zhou, T.; Zheng, A.; Baxa, U.; Chuang, G.-Y.; Georgiev, I.S.; Kong, R.; O’Dell, S.; Shahzad-ul-Hussan, S.; Shen, C.-H.; Tsybovsky, Y.; et al. A Neutralizing Antibody Recognizing Primarily N-Linked Glycan Targets the Silent Face of the HIV Envelope. Immunity 2018, 48, 500-513.e6. [CrossRef]

102. Xu, K.; Acharya, P.; Kong, R.; Cheng, C.; Chuang, G.-Y.; Liu, K.; Louder, M.K.; O’Dell, S.; Rawi, R.; Sastry, M.; et al. Epitope-Based Vaccine Design Yields Fusion Peptide-Directed Antibodies That Neutralize Diverse Strains of HIV-1. Nat. Med. 2018, 24, 857-867. [CrossRef]

103. Scharf, L.; Wang, H.; Gao, H.; Chen, S.; McDowall, A.W.; Bjorkman, P.J. Broadly Neutralizing Antibody 8ANC195 Recognizes Closed and Open States of HIV-1 Env. Cell 2018, 162, 1-13. [CrossRef]

104. Caillat, C.; Guilligay, D.; Sulbaran, G.; Weissenhorn, W. Neutralizing Antibodies Targeting HIV-1 Gp41. Viruses 2020, 12, 1210. [CrossRef]

105. West, A.P., Jr. Structural Basis for Germ-Line Gene Usage of a Potent Class of Antibodies Targeting the CD4-Binding Site of HIV-1 Gp120. Proc. Natl. Acad. Sci. USA 2012,1-8. [CrossRef]

106. Zhou, P.; Yang, X.-L.; Wang, X.-G.; Hu, B.; Zhang, L.; Zhang, W.; Si, H.-R.; Zhu, Y.; Li, B.; Huang, C.-L.; et al. A Pneumonia Outbreak Associated with a New Coronavirus of Probable Bat Origin. Nature 2020, 579, 270-273. [CrossRef]

107. Shiakolas, A.R.; Kramer, K.J.; Wrapp, D.; Richardson, S.I.; Schäfer, A.; Wall, S.; Wang, N.; Janowska, K.; Pilewski, K.A.; Venkat, R.; et al. Cross-Reactive Coronavirus Antibodies with Diverse Epitope Specificities and Fc Effector Functions. Cell Rep. Med. 2021, 2, 100313. [CrossRef]

108. Chi, X.; Yan, R.; Zhang, J.; Zhang, G.; Zhang, Y.; Hao, M.; Zhang, Z.; Fan, P.; Dong, Y.; Yang, Y.; et al. A Neutralizing Human Antibody Binds to the N-Terminal Domain of the Spike Protein of SARS-CoV-2. Science 2020, 369, 650-655. [CrossRef]

109. McCallum, M.; De Marco, A.; Lempp, F.A.; Tortorici, M.A.; Pinto, D.; Walls, A.C.; Beltramello, M.; Chen, A.; Liu, Z.; Zatta, F.; et al. N-Terminal Domain Antigenic Mapping Reveals a Site of Vulnerability for SARS-CoV-2. Cell 2021, 184, 2332-2347.e16. [CrossRef]

110. Song, G.; He, W.; Callaghan, S.; Anzanello, F.; Huang, D.; Ricketts, J.; Torres, J.L.; Beutler, N.; Peng, L.; Vargas, S.; et al. CrossReactive Serum and Memory B-Cell Responses to Spike Protein in SARS-CoV-2 and Endemic Coronavirus Infection. Nat. Commun. 2021, 12, 2938. [CrossRef] 
111. Wang, C.; van Haperen, R.; Gutiérrez-Álvarez, J.; Li, W.; Okba, N.M.A.; Albulescu, I.; Widjaja, I.; van Dieren, B.; FernandezDelgado, R.; Sola, I.; et al. A Conserved Immunogenic and Vulnerable Site on the Coronavirus Spike Protein Delineated by Cross-Reactive Monoclonal Antibodies. Nat. Commun. 2021, 12, 1715. [CrossRef]

112. Pinto, D.; Sauer, M.M.; Czudnochowski, N.; Low, J.S.; Tortorici, M.A.; Housley, M.P.; Noack, J.; Walls, A.C.; Bowen, J.E.; Guarino, B.; et al. Broad Betacoronavirus Neutralization by a Stem Helix-Specific Human Antibody. Science 2021, 373, $1109-1116$. [CrossRef]

113. Sauer, M.M.; Tortorici, M.A.; Park, Y.-J.; Walls, A.C.; Homad, L.; Acton, O.J.; Bowen, J.E.; Wang, C.; Xiong, X.; de van der Schueren, W.; et al. Structural Basis for Broad Coronavirus Neutralization. Nat. Struct. Mol. Biol. 2021, 28, 478-486. [CrossRef]

114. Lv, Z.; Deng, Y.-Q.; Ye, Q.; Cao, L.; Sun, C.-Y.; Fan, C.; Huang, W.; Sun, S.; Sun, Y.; Zhu, L.; et al. Structural Basis for Neutralization of SARS-CoV-2 and SARS-CoV by a Potent Therapeutic Antibody. Science 2020, 369, 1505-1509. [CrossRef] [PubMed]

115. Starr, T.N.; Czudnochowski, N.; Liu, Z.; Zatta, F.; Park, Y.-J.; Addetia, A.; Pinto, D.; Beltramello, M.; Hernandez, P.; Greaney, A.J.; et al. SARS-CoV-2 RBD Antibodies That Maximize Breadth and Resistance to Escape. Nature 2021, 597, 97-102. [CrossRef] [PubMed]

116. Tortorici, M.A.; Czudnochowski, N.; Starr, T.N.; Marzi, R.; Walls, A.C.; Zatta, F.; Bowen, J.E.; Jaconi, S.; Di Iulio, J.; Wang, Z.; et al. Broad Sarbecovirus Neutralization by a Human Monoclonal Antibody. Nature 2021, 597, 103-108. [CrossRef]

117. Lee, E.; Lobigs, M. Substitutions at the Putative Receptor-Binding Site of an Encephalitic Flavivirus Alter Virulence and Host Cell Tropism and Reveal a Role for Glycosaminoglycans in Entry. J. Virol. 2000, 74, 8867-8875. [CrossRef] [PubMed]

118. Watterson, D.; Kobe, B.; Young, P.R.Y. Residues in Domain III of the Dengue Virus Envelope Glycoprotein Involved in Cell-Surface Glycosaminoglycan Binding. J. Gen. Virol. 2012, 93, 72-82. [CrossRef] [PubMed]

119. Chu, J.J.H.; Rajamanonmani, R.; Li, J.; Bhuvanakantham, R.; Lescar, J.; Ng, M.-L.Y. Inhibition of West Nile Virus Entry by Using a Recombinant Domain III from the Envelope Glycoprotein. J. Gen. Virol. 2005, 86, 405-412. [CrossRef]

120. Bhardwaj, S.; Holbrook, M.; Shope, R.E.; Barrett, A.D.T.; Watowich, S.J. Biophysical Characterization and Vector-Specific Antagonist Activity of Domain III of the Tick-Borne Flavivirus Envelope Protein. J. Virol. 2001, 75, 4002-4007. [CrossRef]

121. Modis, Y.; Ogata, S.; Clements, D.; Harrison, S.C. Structure of the Dengue Virus Envelope Protein after Membrane Fusion. Nature 2004, 427, 313-319. [CrossRef]

122. Stiasny, K.; Allison, S.L.; Marchler-Bauer, A.; Kunz, C.; Heinz, F.X. Structural Requirements for Low-PH-Induced Rearrangements in the Envelope Glycoprotein of Tick-Borne Encephalitis Virus. J. Virol. 1996, 70, 8142-8147. [CrossRef]

123. Stiasny, K.; Bressanelli, S.; Lepault, J.; Rey, F.A.; Heinz, F.X. Characterization of a Membrane-Associated Trimeric Low-PH-Induced Form of the Class II Viral Fusion Protein E from Tick-Borne Encephalitis Virus and Its Crystallization. J. Virol. 2004, 78, 3178-3183. [CrossRef]

124. Stettler, K.; Beltramello, M.; Espinosa, D.A.; Graham, V.; Cassotta, A.; Bianchi, S.; Vanzetta, F.; Minola, A.; Jaconi, S.; Mele, F.; et al. Specificity, Cross-Reactivity, and Function of Antibodies Elicited by Zika Virus Infection. Science 2016, 353, 823-826. [CrossRef]

125. Sapparapu, G.; Fernandez, E.; Kose, N.; Bin, C.; Fox, J.M.; Bombardi, R.G.; Zhao, H.; Nelson, C.A.; Bryan, A.L.; Barnes, T.; et al Neutralizing Human Antibodies Prevent Zika Virus Replication and Fetal Disease in Mice. Nature 2016, 540, 443-447. [CrossRef]

126. Deng, Y.-Q.; Dai, J.-X.; Ji, G.-H.; Jiang, T.; Wang, H.-J.; Yang, H.; Tan, W.-L.; Liu, R.; Yu, M.; Ge, B.-X.; et al. A Broadly Flavivirus Cross-Neutralizing Monoclonal Antibody That Recognizes a Novel Epitope within the Fusion Loop of E Protein. PLoS ONE 2011, 6, e16059. [CrossRef]

127. Wang, J.; Bardelli, M.; Espinosa, D.A.; Pedotti, M.; Ng, T.-S.; Bianchi, S.; Simonelli, L.; Lim, E.X.Y.; Foglierini, M.; Zatta, F.; et al. A Human Bi-Specific Antibody against Zika Virus with High Therapeutic Potential. Cell 2017, 171, 229-241.e15. [CrossRef]

128. Rouvinski, A.; Guardado-Calvo, P.; Barba-Spaeth, G.; Duquerroy, S.; Vaney, M.-C.; Kikuti, C.M.; Navarro Sanchez, M.E.; Dejnirattisai, W.; Wongwiwat, W.; Haouz, A.; et al. Recognition Determinants of Broadly Neutralizing Human Antibodies against Dengue Viruses. Nature 2015, 520, 109-113. [CrossRef]

129. Zhang, S.; Kostyuchenko, V.A.; Ng, T.S.; Lim, X.N.; Ooi, J.S.; Lambert, S.; Tan, T.Y.; Widman, D.G.; Shi, J.; Baric, R.S.; et al. Neutralization Mechanism of a Highly Potent Antibody against Zika Virus. Nat. Commun. 2016, 7, 13679. [CrossRef]

130. Dejnirattisai, W.; Jumnainsong, A.; Onsirisakul, N.; Fitton, P.; Vasanawathana, S.; Limpitikul, W.; Puttikhunt, C.; Edwards, C.; Duangchinda, T.; Supasa, S.; et al. Cross-Reacting Antibodies Enhance Dengue Virus Infection in Humans. Science 2010, 328, 745-748. [CrossRef]

131. Oliphant, T.; Engle, M.; Nybakken, G.E.; Doane, C.; Johnson, S.; Huang, L.; Gorlatov, S.; Mehlhop, E.; Marri, A.; Chung, K.M.; et al. Development of a Humanized Monoclonal Antibody with Therapeutic Potential against West Nile Virus. Nat. Med. 2005, 11, 522-530. [CrossRef]

132. Wang, L.; Wang, R.; Wang, L.; Ben, H.; Yu, L.; Gao, F.; Shi, X.; Yin, C.; Zhang, F.; Xiang, Y.; et al. Structural Basis for Neutralization and Protection by a Zika Virus-Specific Human Antibody. Cell Rep. 2019, 26, 3360-3368.e5. [CrossRef] [PubMed]

133. Yu, L.; Wang, R.; Gao, F.; Li, M.; Liu, J.; Wang, J.; Hong, W.; Zhao, L.; Wen, Y.; Yin, C.; et al. Delineating Antibody Recognition against Zika Virus during Natural Infection. JCI Insight 2017, 2. [CrossRef]

134. Wahala, W.M.P.B.; Kraus, A.A.; Haymore, L.B.; Accavitti-Loper, M.A.; de Silva, A.M. Dengue Virus Neutralization by Human Immune Sera: Role of Envelope Protein Domain III-Reactive Antibody. Virology 2009, 392, 103-113. [CrossRef] [PubMed]

135. Slon-Campos, J.L.; Dejnirattisai, W.; Jagger, B.W.; López-Camacho, C.; Wongwiwat, W.; Durnell, L.A.; Winkler, E.S.; Chen, R.E.; Reyes-Sandoval, A.; Rey, F.A.; et al. A Protective Zika Virus E-Dimer-Based Subunit Vaccine Engineered to Abrogate AntibodyDependent Enhancement of Dengue Infection. Nat. Immunol. 2019, 20, 1291-1298. [CrossRef] [PubMed] 
136. Watanabe, S.; Chan, K.W.K.; Wang, J.; Rivino, L.; Lok, S.-M.; Vasudevan, S.G. Dengue Virus Infection with Highly Neutralizing Levels of Cross-Reactive Antibodies Causes Acute Lethal Small Intestinal Pathology without a High Level of Viremia in Mice. J. Virol. 2015, 89, 5847-5861. [CrossRef] [PubMed]

137. Heinz, F.X.; Stiasny, K. Flaviviruses and Flavivirus Vaccines. Vaccine 2012, 30, 4301-4306. [CrossRef]

138. Zhang, X.; Sheng, J.; Plevka, P.; Kuhn, R.J.; Diamond, M.S.; Rossmann, M.G. Dengue Structure Differs at the Temperatures of Its Human and Mosquito Hosts. Proc. Natl. Acad. Sci. USA 2013, 110, 6795-6799. [CrossRef]

139. Victora, G.D.; Nussenzweig, M.C. Germinal Centers. Annu. Rev. Immunol. 2012, 30, 429-457. [CrossRef]

140. Milstein, C.; Neuberger, M.S. Maturation of the Immune Response. In Advances in Protein Chemistry; Richards, F.M., Eisenberg, D.E., Kim, P.S., Eds.; Academic Press: Cambridge, MA, USA, 1996; Volume 49, pp. 451-485. ISBN $0065-3233$.

141. Tiller, T.; Tsuiji, M.; Yurasov, S.; Velinzon, K.; Nussenzweig, M.C.; Wardemann, H. Autoreactivity in Human IgG+ Memory B Cells. 9. Immunity 2007, 26, 205-213. [CrossRef]

142. Davenport, T.M.; Gorman, J.; Joyce, M.G.; Zhou, T.; Soto, C.; Guttman, M.; Moquin, S.; Yang, Y.; Zhang, B.; Doria-Rose, N.A.; et al. Somatic Hypermutation-Induced Changes in the Structure and Dynamics of HIV-1 Broadly Neutralizing Antibodies. Structure 2016, 24, 1346-1357. [CrossRef]

143. Klein, F.; Mouquet, H.; Dosenovic, P.; Scheid, J.F.; Scharf, L.; Nussenzweig, M.C. Antibodies in HIV-1 Vaccine Development and Therapy. Science 2013, 341, 1199-1204. [CrossRef]

144. Kwong, P.D.; Mascola, J.R. HIV-1 Vaccines Based on Antibody Identification, B Cell Ontogeny, and Epitope Structure. Immunity 2018, 48, 855-871. [CrossRef]

145. Klein, F.; Diskin, R.; Scheid, J.F.; Gaebler, C.; Mouquet, H.; Georgiev, I.S.; Pancera, M.; Zhou, T.; Incesu, R.-B.; Fu, B.Z.; et al. Somatic Mutations of the Immunoglobulin Framework Are Generally Required for Broad and Potent HIV-1 Neutralization. Cell 2013, 153, 126-138. [CrossRef]

146. Wagner, S.D.; Milstein, C.; Neuberger, M.S. Codon Bias Targets Mutation. Nature 1995, 376, 732. [CrossRef]

147. Reynaud, C.-A.; Garcia, C.; Hein, W.R.; Weill, J.-C. Hypermutation Generating the Sheep Immunoglobulin Repertoire Is an Antigen-Independent Process. Cell 1995, 80, 115-125. [CrossRef]

148. Briney, B.S.; Willis, J.R.; Crowe, J.E. Location and Length Distribution of Somatic Hypermutation-Associated DNA Insertions and Deletions Reveals Regions of Antibody Structural Plasticity. Genes Immun. 2012, 13, 523-529. [CrossRef]

149. Kepler, T.B.; Liao, H.-X.; Alam, S.M.; Bhaskarabhatla, R.; Zhang, R.; Yandava, C.; Stewart, S.; Anasti, K.; Kelsoe, G.; Parks, R.; et al. Immunoglobulin Gene Insertions and Deletions in the Affinity Maturation of HIV-1 Broadly Reactive Neutralizing Antibodies. Cell Host Microbe 2014, 16, 304-313. [CrossRef]

150. Niu, X.; Yan, Q.; Yao, Z.; Zhang, F.; Qu, L.; Wang, C.; Wang, C.; Lei, H.; Chen, C.; Liang, R.; et al. Longitudinal Analysis of the Antibody Repertoire of a Zika Virus-Infected Patient Revealed Dynamic Changes in Antibody Response. Emerg. Microbes Infect. 2020, 9, 111-123. [CrossRef]

151. Gaebler, C.; Wang, Z.; Lorenzi, J.C.C.; Muecksch, F.; Finkin, S.; Tokuyama, M.; Cho, A.; Jankovic, M.; Schaefer-Babajew, D.; Oliveira, T.Y.; et al. Evolution of Antibody Immunity to SARS-CoV-2. Nature 2021, 591, 639-644. [CrossRef]

152. Wang, Z.; Muecksch, F.; Schaefer-Babajew, D.; Finkin, S.; Viant, C.; Gaebler, C.; Hoffmann, H.-H.; Barnes, C.O.; Cipolla, M.; Ramos, V.; et al. Naturally Enhanced Neutralizing Breadth against SARS-CoV-2 One Year after Infection. Nature 2021, 595, 426-431. [CrossRef]

153. Magnani, D.M.; Silveira, C.G.T.; Rosen, B.C.; Ricciardi, M.J.; Pedreno-Lopez, N.; Gutman, M.J.; Bailey, V.K.; Maxwell, H.S.; Domingues, A.; Gonzalez-Nieto, L.; et al. A Human Inferred Germline Antibody Binds to an Immunodominant Epitope and Neutralizes Zika Virus. PLoS Negl. Trop. Dis. 2017, 11, e0005655. [CrossRef]

154. Rogers, T.F.; Goodwin, E.C.; Briney, B.; Sok, D.; Beutler, N.; Strubel, A.; Nedellec, R.; Le, K.; Brown, M.E.; Burton, D.R.; et al. Zika Virus Activates de Novo and Cross-Reactive Memory B Cell Responses in Dengue-Experienced Donors. Sci. Immunol. 2017, 2, eaan6809. [CrossRef]

155. Gao, F.; Lin, X.; He, L.; Wang, R.; Wang, H.; Shi, X.; Zhang, F.; Yin, C.; Zhang, L.; Zhu, J.; et al. Development of a Potent and Protective Germline-like Antibody Lineage against Zika Virus in a Convalescent Human. bioRxiv 2019, 10, 2424. [CrossRef] [PubMed]

156. Kennedy, R.B. Current Challenges in Vaccinology. Front. Immunol. 2020, 11, 18. [CrossRef] [PubMed]

157. Narkhede, Y.B.; Gonzalez, K.J.; Strauch, E.-M. Targeting Viral Surface Proteins through Structure-Based Design. Viruses 2021, 13, 1320. [CrossRef] [PubMed]

158. Burton, D.R. What Are the Most Powerful Immunogen Design Vaccine Strategies? Reverse Vaccinology 2.0 Shows Great Promise. Cold Spring Harb. Perspect. Biol. 2017, 9, a030262. [CrossRef]

159. Gebara, N.Y.; Kamari, V.E.; Rizk, N. HIV-1 Elite Controllers: An Immunovirological Review and Clinical Perspectives. J. Virus Erad. 2019, 6, 163-166. [CrossRef]

160. Caskey, M.; Schoofs, T.; Gruell, H.; Settler, A.; Karagounis, T.; Kreider, E.F.; Murrell, B.; Pfeifer, N.; Nogueira, L.; Oliveira, T.Y.; et al. Antibody 10-1074 Suppresses Viremia in HIV-1-Infected Individuals. Nat. Med. 2017, 23, 185-191. [CrossRef]

161. Courter, J.R.; Madani, N.; Sodroski, J.; Schön, A.; Freire, E.; Kwong, P.D.; Hendrickson, W.A.; Chaiken, I.M.; LaLonde, J.M.; Smith, A.B. Structure-Based Design, Synthesis and Validation of CD4-Mimetic Small Molecule Inhibitors of HIV-1 Entry: Conversion of a Viral Entry Agonist to an Antagonist. Acc. Chem. Res. 2014, 47, 1228-1237. [CrossRef] 
162. Vita, C.; Drakopoulou, E.; Vizzavona, J.; Rochette, S.; Martin, L.; Ménez, A.; Roumestand, C.; Yang, Y.-S.; Ylisastigui, L.; Benjouad, A.; et al. Rational Engineering of a Miniprotein That Reproduces the Core of the CD4 Site Interacting with HIV-1 Envelope Glycoprotein. Proc. Natl. Acad. Sci. USA 1999, 96, 13091-13096. [CrossRef]

163. Ozorowski, G.; Torres, J.L.; Santos-Martins, D.; Forli, S.; Ward, A.B. A Strain-Specific Inhibitor of Receptor-Bound HIV-1 Targets a Pocket near the Fusion Peptide. Cell Rep. 2020, 33, 108428. [CrossRef]

164. Fischer, W.; Giorgi, E.E.; Chakraborty, S.; Nguyen, K.; Bhattacharya, T.; Theiler, J.; Goloboff, P.A.; Yoon, H.; Abfalterer, W.; Foley, B.T.; et al. HIV-1 and SARS-CoV-2: Patterns in the Evolution of Two Pandemic Pathogens. Cell Host Microbe 2021, 29, 1093-1110. [CrossRef]

165. Hastie, K.M.; Li, H.; Bedinger, D.; Schendel, S.L.; Dennison, S.M.; Li, K.; Rayaprolu, V.; Yu, X.; Mann, C.; Zandonatti, M.; et al. Defining Variant-Resistant Epitopes Targeted by SARS-CoV-2 Antibodies: A Global Consortium Study. Science 2021. [CrossRef]

166. Letko, M.; Marzi, A.; Munster, V. Functional Assessment of Cell Entry and Receptor Usage for SARS-CoV-2 and Other Lineage B Betacoronaviruses. Nat. Microbiol. 2020, 5, 562-569. [CrossRef]

167. Jette, C.A.; Cohen, A.A.; Gnanapragasam, P.N.P.; Muecksch, F.; Lee, Y.E.; Huey-Tubman, K.E.; Schmidt, F.; Hatziioannou, T.; Bieniasz, P.D.; Nussenzweig, M.C.; et al. Broad Cross-Reactivity across Sarbecoviruses Exhibited by a Subset of COVID-19 Donor-Derived Neutralizing Antibodies. Cell Rep. 2021, 36, 109760. [CrossRef]

168. Wec, A.Z.; Wrapp, D.; Herbert, A.S.; Maurer, D.P.; Haslwanter, D.; Sakharkar, M.; Jangra, R.K.; Dieterle, M.E.; Lilov, A.; Huang, D.; et al. Broad Neutralization of SARS-Related Viruses by Human Monoclonal Antibodies. Science 2020, 369, 731-736. [CrossRef]

169. Taylor, P.C.; Adams, A.C.; Hufford, M.M.; de la Torre, I.; Winthrop, K.; Gottlieb, R.L. Neutralizing Monoclonal Antibodies for Treatment of COVID-19. Nat. Rev. Immunol. 2021, 21, 382-393. [CrossRef] [PubMed]

170. Linsky, T.W.; Vergara, R.; Codina, N.; Nelson, J.W.; Walker, M.J.; Su, W.; Barnes, C.O.; Hsiang, T.-Y.; Esser-Nobis, K.; Yu, K.; et al. De Novo Design of Potent and Resilient HACE2 Decoys to Neutralize SARS-CoV-2. Science 2020, 370, 1208-1214. [CrossRef]

171. Bardina, S.V.; Bunduc, P.; Tripathi, S.; Duehr, J.; Frere, J.J.; Brown, J.A.; Nachbagauer, R.; Foster, G.A.; Krysztof, D.; Tortorella, D.; et al. Enhancement of Zika Virus Pathogenesis by Preexisting Antiflavivirus Immunity. Science 2017, 356, 175-180. [CrossRef]

172. Harrison, S.C. Immunogenic Cross-Talk between Dengue and Zika Viruses. Nat. Immunol 2016, 17, 1010-1012. [CrossRef]

173. Priyamvada, L.; Quicke, K.M.; Hudson, W.H.; Onlamoon, N.; Sewatanon, J.; Edupuganti, S.; Pattanapanyasat, K.; Chokephaibulkit, K.; Mulligan, M.J.; Wilson, P.C.; et al. Human Antibody Responses after Dengue Virus Infection Are Highly Cross-Reactive to Zika Virus. Proc. Natl Acad. Sci. USA 2016, 113, 7852-7857. [CrossRef]

174. Vaughn, D.W.; Green, S.; Kalayanarooj, S.; Innis, B.L.; Nimmannitya, S.; Suntayakorn, S.; Endy, T.P.; Raengsakulrach, B.; Rothman, A.L.; Ennis, F.A.; et al. Dengue Viremia Titer, Antibody Response Pattern, and Virus Serotype Correlate with Disease Severity. J. Infect. Dis. 2000, 181, 2-9. [CrossRef]

175. Halstead, S.B. Neutralization and Antibody-Dependent Enhancement of Dengue Viruses. Adv. Virus Res. 2003, 60, $421-467$. [PubMed]

176. Dejnirattisai, W.; Supasa, P.; Wongwiwat, W.; Rouvinski, A.; Barba-Spaeth, G.; Duangchinda, T.; Sakuntabhai, A.; Cao-Lormeau, V.M.; Malasit, P.; Rey, F.A.; et al. Dengue Virus Sero-Cross-Reactivity Drives Antibody-Dependent Enhancement of Infection with Zika Virus. Nat. Immunol. 2016, 17, 1102-1108. [CrossRef] [PubMed]

177. Wahala, W.M.; Silva, A.M. The Human Antibody Response to Dengue Virus Infection. Viruses 2011, 3, 2374-2395. [CrossRef] [PubMed]

178. De Alwis, R.; Williams, K.L.; Schmid, M.A.; Lai, C.-Y.; Patel, B.; Smith, S.A.; Crowe, J.; Wang, W.-K.; Harris, E.; De Silva, A.M. Dengue Viruses Are Enhanced by Distinct Populations of Serotype Cross-Reactive Antibodies in Human Immune Sera. PLoS Pathog. 2014, 10, e1004386. [CrossRef]

179. Nisalak, A.; Clapham, H.E.; Kalayanarooj, S.; Klungthong, C.; Thaisomboonsuk, B.; Fernandez, S.; Reiser, J.; Srikiatkhachorn, A.; Macareo, L.R.; Lessler, J.T.; et al. Forty Years of Dengue Surveillance at a Tertiary Pediatric Hospital in Bangkok, Thailand, 1973-2012. Am. J. Trop. Med. Hyg. 2016, 94, 1342-1347. [CrossRef]

180. Sangkawibha, N.; Rojanasuphot, S.; Ahandrik, S.; Viriyapongse, S.; Jatanasen, S.; Salitul, V.; Phanthumachinda, B.; Halstead, S.B. Risk Factors in Dengue Shock Syndrome: A Prospective Epidemiologic Study in Rayong, Thailand: I. The 1980 Outbreak. Am. J. Epidemiol. 1984, 120, 653-669. [CrossRef]

181. Katzelnick, L.C.; Narvaez, C.; Arguello, S.; Mercado, B.L.; Collado, D.; Ampie, O.; Elizondo, D.; Miranda, T.; Carillo, F.B.; Mercado, J.C.; et al. Zika Virus Infection Enhances Future Risk of Severe Dengue Disease. Science 2020, 369, 1123-1128. [CrossRef]

182. Halstead, S.B. In Vivo Enhancement of Dengue Virus Infection in Rhesus Monkeys by Passively Transferred Antibody. J. Infect. Dis. 1979, 140, 527-533. [CrossRef]

183. Waggoner, J.J.; Katzelnick, L.C.; Burger-Calderon, R.; Gallini, J.; Moore, R.H.; Kuan, G.; Balmaseda, A.; Pinsky, B.A.; Harris, E. Antibody-Dependent Enhancement of Severe Disease Is Mediated by Serum Viral Load in Pediatric Dengue Virus Infections. J. Infect. Dis. 2020, 221, 1846-1854. [CrossRef]

184. Katzelnick, L.C.; Gresh, L.; Halloran, M.E.; Mercado, J.C.; Kuan, G.; Gordon, A.; Balmaseda, A.; Harris, E. Antibody-Dependent Enhancement of Severe Dengue Disease in Humans. Science 2017, 358, 929-932. [CrossRef] 
185. Salje, H.; Cummings, D.A.T.; Rodriguez-Barraquer, I.; Katzelnick, L.C.; Lessler, J.; Klungthong, C.; Thaisomboonsuk, B.; Nisalak, A.; Weg, A.; Ellison, D.; et al. Reconstruction of Antibody Dynamics and Infection Histories to Evaluate Dengue Risk. Nature 2018, 557, 719-723. [CrossRef] [PubMed]

186. Cattarino, L.; Rodriguez-Barraquer, I.; Imai, N.; Cummings, D.A.T.; Ferguson, N.M. Mapping Global Variation in Dengue Transmission Intensity. Sci. Transl. Med. 2020, 12, eaax4144. [CrossRef] [PubMed]

187. Faria, N.R.; Quick, J.; Claro, I.M.; Thézé, J.; de Jesus, J.G.; Giovanetti, M.; Kraemer, M.U.G.; Hill, S.C.; Black, A.; da Costa, A.C.; et al. Establishment and Cryptic Transmission of Zika Virus in Brazil and the Americas. Nature 2017, 546, 406-410. [CrossRef] [PubMed]

188. Yang, C.; Zeng, F.; Gao, X.; Zhao, S.; Li, X.; Liu, S.; Li, N.; Deng, C.; Zhang, B.; Gong, R. Characterization of Two Engineered Dimeric Zika Virus Envelope Proteins as Immunogens for Neutralizing Antibody Selection and Vaccine Design. J. Biol. Chem. 2019, 294, 10638-10648. [CrossRef]

189. Cimica, V.; Williams, S.; Adams-Fish, D.; McMahon, C.; Narayanan, A.; Rashid, S.; Stedman, T.T. Zika Virus-Like Particle (VLP) Vaccine Displaying Envelope (E) Protein CD Loop Antigen Elicits Protective and Specific Immune Response in a Murine Model. Biochem. Biophys. Res. Commun. 2020, 529, 805-811. [CrossRef]

190. Tai, W.; Chen, J.; Zhao, G.; Geng, Q.; He, L.; Chen, Y.; Zhou, Y.; Li, F.; Du, L. Rational Design of Zika Virus Subunit Vaccine with Enhanced Efficacy. J. Virol. 2019, 93, e02187-18. [CrossRef]

191. Shanmugam, R.K.; Ramasamy, V.; Shukla, R.; Arora, U.; Swaminathan, S.; Khanna, N. Pichia Pastoris-Expressed Zika Virus Envelope Domain III on a Virus-like Particle Platform: Design, Production and Immunological Evaluation. Pathog. Dis. 2019, 77, ftz026. [CrossRef]

192. Yang, M.; Lai, H.; Sun, H.; Chen, Q. Virus-like Particles That Display Zika Virus Envelope Protein Domain III Induce Potent Neutralizing Immune Responses in Mice. Sci. Rep. 2017, 7, 7679. [CrossRef]

193. Espinosa, D.; Mendy, J.; Manayani, D.; Vang, L.; Wang, C.; Richard, T.; Guenther, B.; Aruri, J.; Avanzini, J.; Garduno, F.; et al. Passive Transfer of Immune Sera Induced by a Zika Virus-Like Particle Vaccine Protects AG129 Mice Against Lethal Zika Virus Challenge. EBioMedicine 2018, 27, 61-70. [CrossRef]

194. Cabral-Miranda, G.; Lim, S.M.; Mohsen, M.O.; Pobelov, I.V.; Roesti, E.S.; Heath, M.D.; Skinner, M.A.; Kramer, M.F.; Martina, B.E.E.; Bachmann, M.F. Correction: Zika Virus-Derived E-DIII Protein Displayed on Immunologically Optimized VLPs Induces Neutralizing Antibodies without Causing Enhancement of Dengue Virus Infection. Vaccines 2020, 8, 94. [CrossRef] 